\title{
Nitrogen cycling in the Southern Ocean Kerguelen Plateau area: evidence for significant surface nitrification from nitrate isotopic compositions
}

\author{
F. Dehairs ${ }^{1}$, F. Fripiat ${ }^{1}$, A.-J. Cavagna ${ }^{1}$, T. W. Trull ${ }^{2,3,4}$, C. Fernandez ${ }^{5,6}$, D. Davies ${ }^{2,3}$, A. Roukaerts ${ }^{1}$, \\ D. Fonseca Batista ${ }^{1}$, F. Planchon ${ }^{7}$, and M. Elskens ${ }^{1}$ \\ ${ }^{1}$ Analytical, Environmental and Geo - Chemistry; Earth System Sciences Research Group, \\ Vrije Universiteit Brussel, Belgium \\ ${ }^{2}$ CSIRO Marine and Atmospheric Research, Hobart, Tasmania, Australia \\ ${ }^{3}$ Antarctic Climate and Ecosystems Cooperative Research Centre, Hobart, Tasmania, Australia \\ ${ }^{4}$ Institute for Marine and Antarctic Studies, University of Tasmania, Hobart, Tasmania, Australia \\ ${ }^{5}$ Sorbonne Universités, UPMC Univ Paris 06, UMR7621, Laboratoire d'Océanographie Microbienne, \\ Observatoire Océanologique, 66650 Banyuls/mer, France \\ ${ }^{6}$ Department of Oceanography, COPAS SurAustral program and Interdisciplinary center for Aquaculture Research (INCAR), \\ University of Concepción, Chile \\ ${ }^{7}$ Laboratoire des Sciences de L'Environnement Marin (LEMAR) Université de Bretagne Occidentale, \\ Institut Européen de la Mer, Plouzané, Brest, France
}

Correspondence to: F. Dehairs (fdehairs@vub.ac.be)

Received: 3 September 2014 - Published in Biogeosciences Discuss.: 26 September 2014

Revised: 28 January 2015 - Accepted: 3 February 2015 - Published: 5 March 2015

\begin{abstract}
This paper presents whole water column data for nitrate N, O isotopic composition for the Kerguelen Plateau area and the basin extending east of Heard Island, aiming at understanding the $\mathrm{N}$-cycling in this naturally iron fertilized area that is characterized by large re-current phytoplankton blooms. The KEOPS 2 expedition (OctoberNovember 2011) took place in spring season and complements knowledge gathered during an earlier summer expedition to the same area (KEOPS 1, February-March 2005). As noted by others a remarkable condition of the system is the moderate consumption of nitrate over the season (nitrate remains $>20 \mu \mathrm{M}$ ) while silicic acid becomes depleted, suggesting significant recycling of nitrogen. Nitrate isotopic signatures in the upper water column do mimic this condition, with surprising overlap of spring and summer regressions of $\delta^{18} \mathrm{O}_{\mathrm{NO}_{3}}$ vs. $\delta^{15} \mathrm{~N}_{\mathrm{NO}_{3}}$ isotopic compositions. These regressions obey rather closely the ${ }^{18} \varepsilon /{ }^{15} \varepsilon$ discrimination expected for nitrate uptake $\left({ }^{18} \varepsilon /{ }^{15} \varepsilon=1\right)$, but regression slopes as large as 1.6 were observed for the mixed layer above the Kerguelen Plateau. A preliminarily mass balance
\end{abstract}

calculation for the early bloom period points toward significant nitrification occurring in the mixed layer and which may be equivalent to up to $47 \%$ of nitrate uptake above the Kerguelen Plateau. A further finding concerns deep ocean low $\delta^{18} \mathrm{O}_{\mathrm{NO}_{3}}$ values $(<2 \%$ ) underlying high chlorophyll waters at the Polar Front Zone and which cannot be explained by remineralization and nitrification of the local particulate nitrogen flux, which is too small in magnitude. However, the studied area is characterized by a complex recirculation pattern that would keep deep waters in the area and could impose a seasonally integrated signature of surface water processes on the deep waters.

\section{Introduction}

The Kerguelen Plateau and leeward off-shelf areas are characterized by intense seasonal phytoplankton blooms, which are sustained by enhanced iron supply from deep water (Blain et al., 2007, 2008). While these intense blooms re- 
sult in strong silicic acid depletion, their impact on depletion of the nitrate stocks is much smaller, with end-of-bloom surface water nitrate concentrations still very high, as observed during the KEOPS 1 expedition in late summer 2005 (Blain et al. 2007; Mosseri et al., 2008). Relative to the magnitude of primary production the bloom areas are characterized by enhanced shallow remineralization and reduced deep sea export, as compared to off-shelf areas located outside the bloom patch (Jacquet et al., 2008). Mosseri et al. (2008) report that despite silicic acid and nitrate uptake ratios being close to 1 , the apparent nitrate consumption over the season was much lower than the silicic acid consumption, implying significant shallow remineralization of $\mathrm{N}$, as evidenced by substantial subsurface ammonium concentrations, reaching up to $2 \mu \mathrm{M}$ (Mosseri et al., 2008). It is likely that such conditions would also favour a surface ocean development of nitrifying Bacteria and Archaea, with some members of the latter group known to have affinities for ammonium equaling and even exceeding those of diatoms (Martens-Habbena et al., 2009; Stahl and de la Torre, 2012).

Several authors have highlighted that knowledge about nitrate stable isotope composition is an essential asset to resolve the complex suite of processes that control the oceanic N cycle (see e.g., Sigman et al., 1999; DiFiore et al., 2006; 2009; Rafter et al., 2013). During the early season KEOPS 2 expedition (October-November) to the Kerguelen area, we analysed the $\mathrm{N}$ and $\mathrm{O}$ stable isotope composition of nitrate over the whole water column to investigate possible imprints of the above-described shallow remineralization + nitrification process, as well as imprints of enhanced primary production on deep ocean nitrate isotopic composition. Furthermore, this early season expedition offered the opportunity to investigate the seasonal variability of the nitrate isotopic composition, by comparing results with those obtained earlier by others during the late summer KEOPS 1 expedition to the same area (Trull et al., 2008). This work on nitrate isotopic composition takes advantage of the study of primary production, nitrate and ammonium uptake, carbon export production and remineralization that was conducted by others during the KEOPS 2 expedition (Cavagna et al., 2014; Planchon et al., 2014; Jacquet et al., 2014).

Confirming previous studies, combined measurement of nitrate dual isotope composition and $\mathrm{N}$-nutrient uptake rate measurements, as performed during KEOPS 2, appears to be particularly useful for investigating surface ocean $\mathrm{N}$ processes. In that aspect this study differs from previous studies on nitrogen cycling using the natural nitrate dual isotopic composition, but lacking information on N-process rates. The present study also adds significantly to the existing database on nitrate isotopic composition in the Southern Ocean, with new data for the Polar Front region in a naturally iron-fertilized area.

\section{Methods}

\subsection{Site description}

The studied area covers the broad plateau region stretching between Kerguelen and Heard Island to the SE, and the deep basin to the east of the island (Fig. 1). This basin is bound to the south by the Kerguelen Plateau and to the north by a sill (Gallieni Spur) extending from the plateau in the northeasterly direction (Fig. 1).

Briefly, the studied area to the east of Kerguelen is crossed by the meandering Polar Front, which circumvents the island from the southwest, crosses the shallow $(\sim 500 \mathrm{~m})$ Kerguelen Plateau (which extends in a southeasterly direction from the island) and forms a loop extending northward up to the sill that borders the basin to the north (Gallieni Spur), thereby enclosing a stable mesoscale meander structure (Fig. 1). Surface and subsurface waters closely follow, and actually define the position of the PF. Deep water flow in the area is fed by circumpolar deep water flow channelled through the Fawn Trough (Park et al., 2008) and also by the northward-directed deep western boundary current in the Australian Antarctic basin east of the Kerguelen Plateau (McCartney and Donohue, 2007; Fukamachi et al., 2010).

For further details about the topography and the largescale circulation in the Kerguelen Island and Plateau areas we refer to Park et al. (2008).

The $T-S$ diagram (Fig. 1) highlights the hydrodynamic environment of the Kerguelen area, with profiles characteristic of the Open Ocean Zone. The most salient features are: highest temperatures in surface waters; presence of subsurface temperature minimum Winter Water; increased temperatures in Upper Circumpolar Deep Water; increased salinities in Lower Circumpolar Deep Water; a broad salinity maximum reflecting the remnant North Atlantic Deep Water; slightly less saline and cold Bottom Waters.

\subsection{Sampling and analysis}

The KEOPS 2 expedition took place from October to early November 2011 on board R/V Marion Dufresne. The sampling strategy aimed at documenting both the short-term temporal evolution of the system during pre- and bloom conditions of selected sites and the broader spatial variability between Plateau and more off-shelf sites (Fig. 1b shows the map with the MODIS chlorophyll pattern superimposed). Short-term temporal evolution was followed in a stationary meander of the Polar Front and by revisiting sites above the Plateau, while spatial variability was studied along a W-E section and a N-S section covering the Plateau and the basin east of Kerguelen Island.

The water column was sampled per CTD rosette equipped with $12 \mathrm{~L}$ Niskin bottles. N-nutrients (nitrate, nitrite, ammonium) were measured onboard using classical spectrophotometric methods (Blain et al., 2015). The samples for ni- 

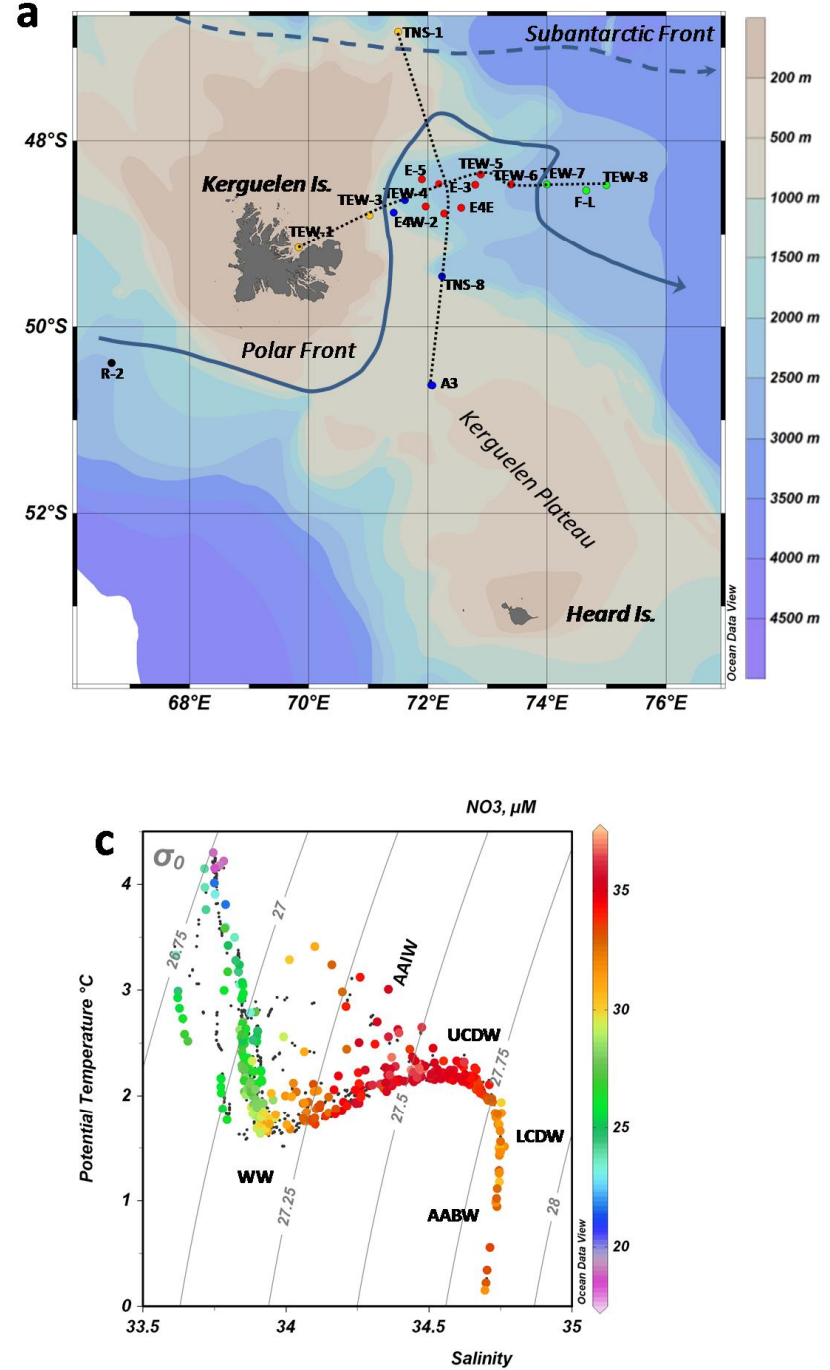

b

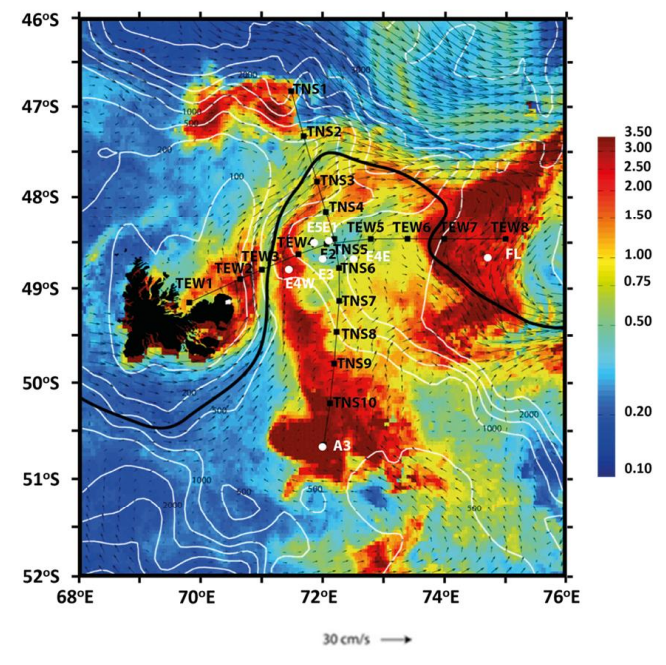

Figure 1. (a) Kerguelen area with KEOPS 2 sampling grid. Blue dots: "Plateau" stations; red dots: "Meander" stations; green dots: stations at the Polar Front and north of the PF; black dot: "reference" station; orange dots: stations outside the Plateau and Meander areas. The black line marks the position of the Polar Front. (b) MODIS chlorophyll distribution for second half of November 2011 (colour bar: $\mu \mathrm{g} \mathrm{L}^{-1}$ ); arrows represent the current speed, with scale marked by the small black arrow $\left(30 \mathrm{~cm} \mathrm{~s}^{-1}\right.$ ) below the figure (courtesy F. d'Ovidio and Y.-H. Park); (c) $T-S$ diagram (all stations) with $\left[\mathrm{NO}_{3}^{-}\right]$superimposed. (ODV-AWI, R. Schlitzer).

trate isotopic composition consisted of a subfraction $(10 \mathrm{~mL})$ of the filtered seawater (Acrodisc; $0.2 \mu \mathrm{m}$ porosity) intended for on-board nitrate + nitrite analysis. These subsamples were kept frozen $\left(-20^{\circ} \mathrm{C}\right)$ until analysis in the homebased laboratory. The nitrogen and oxygen isotopic composition of nitrate was determined via the bacterial denitrifier method, using Pseudomonas aureofaciens bacteria which reduce nitrate to $\mathrm{N}_{2} \mathrm{O}$ (Sigman et al., 2001; Casciotti et al., 2002). We aimed at a final homogeneous nitrate content of $20 \mathrm{nmol}$ for samples and reference standards alike (see below). The analytical equipment consisted of a custom-built gas bench connected on-line to a set-up for gas conditioning, which involved elimination of volatile organic carbon compounds, $\mathrm{CO}_{2}$ and cryogenic focusing of $\mathrm{N}_{2} \mathrm{O}$, GC sep- aration of $\mathrm{CO}_{2}$ traces from $\mathrm{N}_{2} \mathrm{O}$, a Con-Flo unit and IRMS (Thermo Delta V). For final calculations we used the USGS 32, 34, 35 and IAEA N3 international reference standards (Sigman et al., 2001; Böhlke et al., 2003) and the twopoint normalization procedure as discussed in Casciotti et al. (2002) and Paul et al. (2007). $\delta^{15} \mathrm{~N}$ values are reported as $\left[\left({ }^{15} \mathrm{~N} /{ }^{14} \mathrm{~N}_{\text {sample }}\right) /\left({ }^{14} \mathrm{~N} /{ }^{15} \mathrm{~N}\right)_{\text {ref }}-1\right] \times 1000$, referenced to Air $\mathrm{N}_{2}$ and $\delta^{18} \mathrm{O}$ as $\left[\left({ }^{18} \mathrm{O} /{ }^{16} \mathrm{O}\right)_{\text {sample }} /\left({ }^{18} \mathrm{O} /{ }^{16} \mathrm{O}\right)_{\text {ref }}-1\right] \times$ 1000 , referenced to VSMOW. Multiple analyses of USGS and IAEA reference solutions indicate that average measurement errors for $\delta^{15} \mathrm{~N}_{\mathrm{NO}_{3}}$ and $\delta^{18} \mathrm{O}_{\mathrm{NO}_{3}}$ analyses were 0.17 and $0.38 \%$, respectively. We also analysed 35 duplicate samples from successive CTD casts at same depths yielding median 
values of the standard deviations of 0.05 and $0.28 \%$ for $\delta^{15} \mathrm{~N}$ and $\delta^{18} \mathrm{O}$, respectively.

Note that the method measures the isotopic composition of $\mathrm{NO}_{3}^{-}$plus $\mathrm{NO}_{2}^{-}$. The presence even of small nitrite amounts would lower the $\delta^{15} \mathrm{~N}$ and $\delta^{18} \mathrm{O}$ values of nitrate + nitrite relative to nitrate only (Casciotti et al., 2007). In the present study the effect of $\mathrm{NO}_{2}^{-}$was neglected since overall nitrite concentrations were small, representing on average $<0.5 \%$ of the nitrate + nitrite pool (see also DiFiore et al., 2009). However, it has been reported that slightly higher nitrite levels reaching $0.8 \%$ of the nitrite + nitrate pool such as observed here for the surface waters can result in a lowering of the $\delta^{15} \mathrm{~N}$ and $\delta^{18} \mathrm{O}$ values by 0.4 and $0.2 \%$ on average (Rafter et al., 2013; their Supplement). We have not corrected our surface water nitrate isotopic values for a possible nitrite effect, as is the case also in work presented by others (see e.g., DiFiore et al., 2009; Rafter et al., 2013), but have considered the impact of this when calculating nitrification (see Sect. 4.5). Information on nitrate, ammonium uptake experiments and $\mathrm{C}, \mathrm{N}$ Export flux via the ${ }^{234} \mathrm{Th}$ method is given in the contributions by Cavagna et al. (2014) and Planchon et al. (2014). As part of the analysis protocol for assessing carbon export via the ${ }^{234} \mathrm{Th}$ method, we also analysed $\delta^{15} \mathrm{~N}$ of suspended particulate nitrogen in the size fractions 1 to 53 and $>53 \mu \mathrm{m}$, as sampled with large-volume in situ pumps (Planchon et al., 2014).

\section{Results}

The full data set $\left(\delta^{15} \mathrm{~N}_{\mathrm{NO}_{3}}, \delta^{18} \mathrm{O}_{\mathrm{NO}_{3}}\right.$, concentrations of $\mathrm{NO}_{3}^{-}$, $\mathrm{NO}_{2}^{-}, \mathrm{NH}_{4}^{+}$, Salinity, $T_{\text {pot }}$ and density) is available in Appendix Table A1.

A total of 20 sites were sampled for analysis of nitrate isotopic composition. One site located southwest of Kerguelen, in HNLC waters well outside the Kerguelen bloom, was taken as reference site (R-2; Table 1). We differentiate three regions (Table 1): (i) plateau stations located south of the $\mathrm{PF}$, above the shallow Plateau and the margin and underlying the bloom plume (stations A3-1, TNS-8, TEW-4, E4W, A3-2, E-4W-2); (ii) Polar Front Meander stations in the central part of the basin east of Kerguelen where the bloom had not fully developed yet (stations TNS-6, E-1, TEW-5, TEW-6, E-3, E-4E, E-5, IODA-REC); (iii) Polar Front and north of Polar Front sites (stations TEW-7, TEW-8, F-L). Average upper $100 \mathrm{~m} \mathrm{Chl} a$ concentrations are highest for the Polar Front stations $\left(2.03 \pm 0.43 \mu \mathrm{g} \mathrm{L}^{-1}\right)$, followed by the Plateau stations $\left(1.27 \pm 0.54 \mu \mathrm{g} \mathrm{L}^{-1}\right)$, while the Meander sites had lower Chl $a$ concentrations $\left(0.85 \pm 0.32 \mu \mathrm{g} \mathrm{L}^{-1}\right)$, though clearly in excess of values recorded for the HNLC reference station $\left(0.3 \mu \mathrm{g} \mathrm{L}^{-1}\right)$ (Table 1$)$. We note that Plateau sites on average have the coldest $\left(2.27 \pm 0.34{ }^{\circ} \mathrm{C}\right)$ and most saline $(33.89 \pm 0.02)$ surface waters (upper $100 \mathrm{~m}$ ), while PF sites have the warmest $\left(3.49 \pm 0.24^{\circ} \mathrm{C}\right)$ and freshest $(33.79 \pm 0.02)$ surface waters (Table 1$)$. Average nitrate val- ues in the upper $100 \mathrm{~m}$ of water column remain high throughout the study period with average values of $26.6 \pm 1.9$; $26.2 \pm 0.9$ and $23.1 \pm 1.3 \mu \mathrm{M}$ for Plateau, Meander and PF areas, respectively (Table 1). With increasing depth, nitrate concentrations in general increase to reach maximal values around $37 \mu \mathrm{M}$ at $500 \mathrm{~m}$ in Upper Circumpolar Deep waters (UCDW) (Fig. 2a). Concentrations decrease slightly in Lower Circumpolar Deep Waters (around $30 \mu \mathrm{M}$ ) and increase again slightly in bottom waters (around $32 \mu \mathrm{M}$ ). Profiles of $\delta^{15} \mathrm{~N}_{\mathrm{NO}_{3}}$ mirror the ones of nitrate (Fig. 2b): high values in surface waters (reaching up to $7.5 \%$ ) which decrease to $4.6 \%$ in the $\mathrm{NO}_{3}^{-}$maximum and increase slightly to $5 \%$ o at about $2500 \mathrm{~m}$. A slight decrease of $\delta^{15} \mathrm{~N}_{\mathrm{NO}_{3}}$ is noticed in Polar Front bottom waters which also show a slight increase in nitrate concentration (Fig. 2a, b). Such values are similar to those observed widely for the deep ocean (see Di-Fiore et al., 2009; Sigman et al., 2000, 2009b; Rafter et al., 2013). Although $\delta^{18} \mathrm{O}_{\mathrm{NO}_{3}}$ values are more scattered, it can be clearly seen that they follow a pattern similar to $\delta^{15} \mathrm{~N}_{\mathrm{NO}_{3}}$, with values up to $6 \%$ in surface waters, which decrease to $<2 \%$ in the 500 to $1000 \mathrm{~m}$ depth interval but tend to increase again in deep and bottom waters and stay close to $2 \%$ (Fig. 2c).

Figure $3 \mathrm{a}$ and $\mathrm{b}$ show the spatial distribution of the $\delta^{15} \mathrm{~N}_{\mathrm{NO}_{3}}$ and $\delta^{18} \mathrm{O}_{\mathrm{NO}_{3}}$ signals and nitrate concentration along the W-E and S-N transects. Deep waters $(>500 \mathrm{~m})$ in the central part of the W-E section, between 72 and $74^{\circ} \mathrm{E}$, have $\delta^{15} \mathrm{~N}_{\mathrm{NO}_{3}}$ values close to $5 \%$, while westward and eastward of this central area, deep waters have slightly lower $\delta^{15} \mathrm{~N}$ values (Fig. 3, top). Lowest $\delta^{15} \mathrm{~N}_{\mathrm{NO}_{3}}$ values are observed in bottom waters $(>2000 \mathrm{~m})$ east of $73^{\circ} \mathrm{E}$ and appear associated with very low temperatures $\left(<1^{\circ} \mathrm{C}\right)$. These waters are probably of southerly origin, associated with the Fawn Trough Current, transporting cold Antarctic waters of eastern Enderby origin (Park et al., 2008) and possibly also partly with the Deep Western Boundary Current which is part of the deep cyclonic gyre in the Australian-Antarctic Basin (McCartney and Donohue, 2007; Fukamachi et al., 2010).

Differences of the $\delta^{15} \mathrm{~N}$ and $\delta^{18} \mathrm{O}$ gradients between deep ocean and surface are generally visualized by plotting the $\Delta(15-18)$ values, which have been defined (Sigman et al., 2005) as: the difference between $\delta^{15} \mathrm{~N}$ and $\delta^{18} \mathrm{O}$ (Rafter et al., 2013 ), keeping in mind that for deep waters the $\delta^{15} \mathrm{~N}_{\mathrm{NO}_{3}}$ $\delta^{18} \mathrm{O}_{\mathrm{NO}_{3}}$ difference is close to $3 \%$. From Fig. 2d it appears that surface waters have $\Delta(15-18)$ values generally $<3 \%$ o (range $0.9-3 \%$; average $=2.30 \pm 0.5 \%$ ) , with lowest values observed for Plateau, PF areas, and Meander stations. This indicates that surface water $\delta^{18} \mathrm{O}$ values have increased more than $\delta^{15} \mathrm{~N}$ values. In contrast, the subsurface waters between 250 and $1250 \mathrm{~m}$ show a majority of data points with $\Delta(15-$ 18 ) values $>3 \%$, though values are scattered rather widely. Since uptake of nitrate fractionates ${ }^{15} \mathrm{~N} /{ }^{14} \mathrm{~N}$ and ${ }^{18} \mathrm{O} /{ }^{16} \mathrm{O}$ equally (Granger et al., 2004; Sigman et al., 2005), another process needs to be invoked to explain the low $\Delta(15-18)$ values for surface waters. In the discussion below we show that 


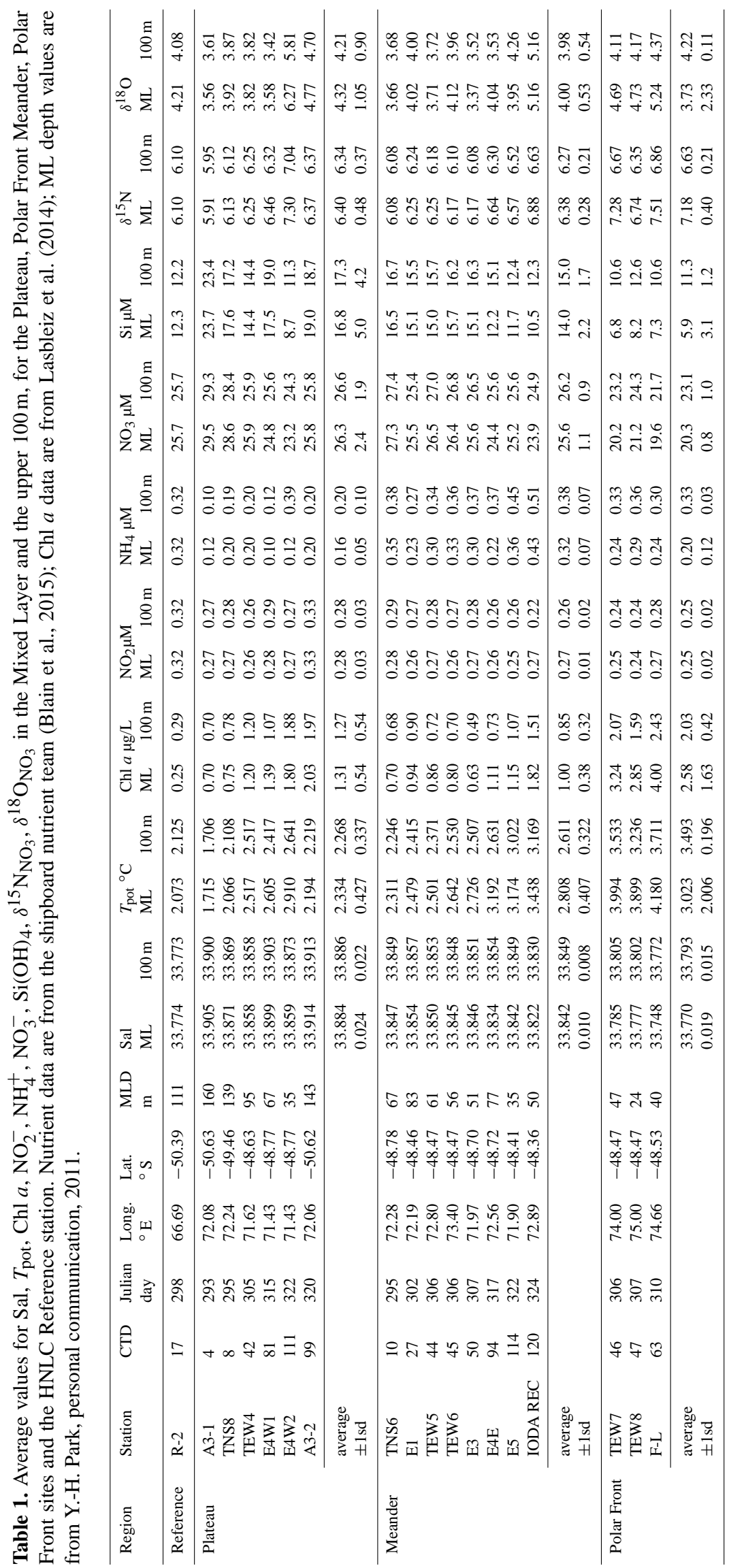



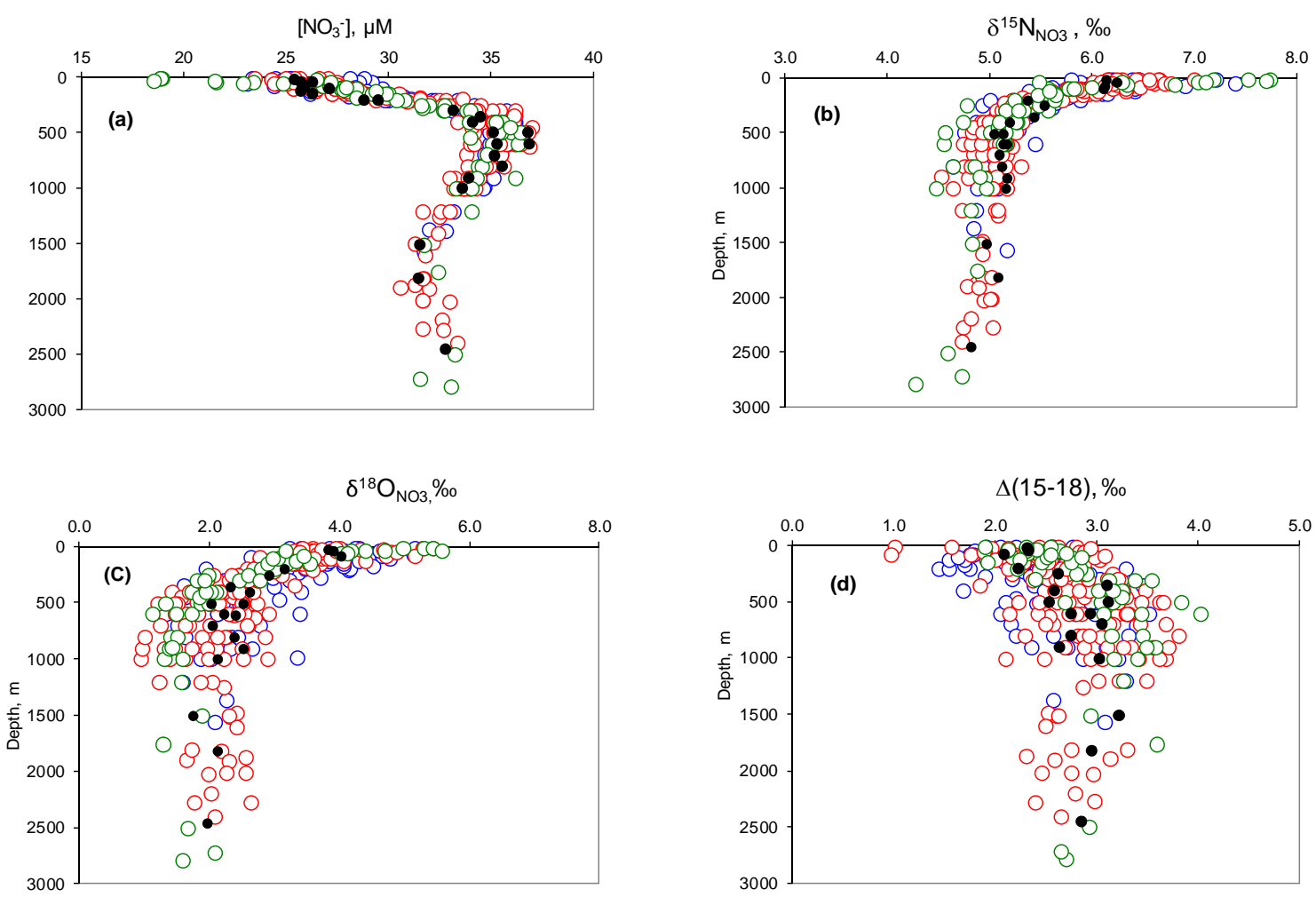

Figure 2. Water column profiles of (a) $\mathrm{NO}_{3}^{-}(\mu \mathrm{M})$; (b) $\delta^{15} \mathrm{~N}_{\mathrm{NO}_{3}}$; (c) $\delta^{18} \mathrm{O}_{\mathrm{NO}_{3}}$, and (d) $\Delta(15-18)$; Complete data set. Blue circles: Plateau stations; red circles: Meander stations; green circles: Polar Front and north of PF stations; filled black circle: reference station (R-2).

these low surface water $\Delta(15-18)$ values $(<3 \%$ ) can be attributed largely to a partial utilization of the surface water nitrate pool combined with nitrification in the surface and subsurface waters.

For the 250-1500 m depth interval at stations on the PFZ side of the PF (east of $74^{\circ} \mathrm{E}$ ) and to a lesser stations close to the plateau margin between 71 and $72^{\circ} \mathrm{E}$ (Fig. 3a) we observe low $\delta^{18} \mathrm{O}_{\mathrm{NO}_{3}}$ values $(<2 \%$ ) and high $\Delta(15-18)$ values (>3\%o; Fig. 2d). This feature is probably associated with advection of UCDW as discussed later. The occurrence of these signals at the western and eastern borders of the meander possibly reflects the presence of a cyclonic circulation in the basin which confines the meander, as reported by Park et al. (2014). Note that the $\mathrm{S}-\mathrm{N}$ section between approximately 71 and $72^{\circ} \mathrm{E}$ also intersects the low $\delta^{18} \mathrm{O}_{\mathrm{NO}_{3}}$ waters (see Fig. 3b). Below $1500 \mathrm{~m} \Delta(15-18)$ values are close to $3 \%$, reflecting similar vertical gradients for $\delta^{15} \mathrm{~N}$ and $\delta^{18} \mathrm{O}$.

\section{Discussion}

\subsection{Nitrate concentration and isotopic composition}

The clear ${ }^{15} \mathrm{~N},{ }^{18} \mathrm{O}$ enrichments of nitrate in the upper ocean (Fig. 2) suggest a strong effect of isotopic discrimination during nitrate uptake by the phytoplankton (Sigman et al., 1999; DiFiore et al., 2010). The isotope fractiona- tion effect is visualized by plotting $\delta^{15} \mathrm{~N}_{\mathrm{NO}_{3}}$ and $\delta^{18} \mathrm{O}_{\mathrm{NO}_{3}}$ values vs. the natural logarithm of nitrate concentration (Fig. 4). The degree of linearity of these relationships is indicative of the degree by which isotopic discrimination approaches closed system Rayleigh fractionation. The slope values of these regressions are equivalent to apparent discrimination factors $(\varepsilon)$. Whole water column values are $-4.08 \pm 0.17( \pm \mathrm{SE}),-4.18 \pm 0.20$ and $-4.54 \pm 0.21$, for Meander, Polar Front and Plateau areas, respectively (Fig. 4). When focusing on the upper $250 \mathrm{~m}$ (this layer partly includes UCDW), slopes are slightly steeper, reaching $-4.62 \pm 0.21,-4.44 \pm 0.23$ and $-4.76 \pm 0.36$, respectively (Fig. 4). Slopes for $\delta^{18} \mathrm{O}_{\mathrm{NO}_{3}}$ are steeper than for $\delta^{15} \mathrm{~N}$, reaching $-6.15 \pm 0.37,-6.20 \pm 0.39$ and $-6.75 \pm 0.56$ for the whole water column and $-6.15 \pm 0.87,-5.18 \pm 0.52$ and $-6.13 \pm 1.03$, for the upper $250 \mathrm{~m}$, for Meander, Polar Front and Plateau, respectively (Fig. 4). We thus observe a tendency for slopes of $\delta^{15} \mathrm{~N}_{\mathrm{NO}_{3}}$ vs. $\mathrm{LN}\left[\mathrm{NO}_{3}^{-}\right]$to increase in shallow waters, while on the contrary slopes for $\delta^{18} \mathrm{O}_{\mathrm{NO}_{3}}$ vs. $\mathrm{LN}\left[\mathrm{NO}_{3}^{-}\right]$decrease. Largest $\delta^{15} \mathrm{~N}, \delta^{18} \mathrm{O}$ slope values are observed for the Plateau sites. Overall such values fit within the range of $\varepsilon$ values reported for nitrate uptake by phytoplankton $\left(4-10 \%\right.$ o for ${ }^{15} \varepsilon$ and ${ }^{18} \varepsilon$; DiFiore et al., 2010; Sigman et al., 2009a, b; Granger et al., 2004, 2010). The high whole water column slope values for $\delta^{18} \mathrm{O}$ are in part due to the low $\delta^{18} \mathrm{O}$ values $(<2 \%$ ) of deep waters (LCDW and bottom 

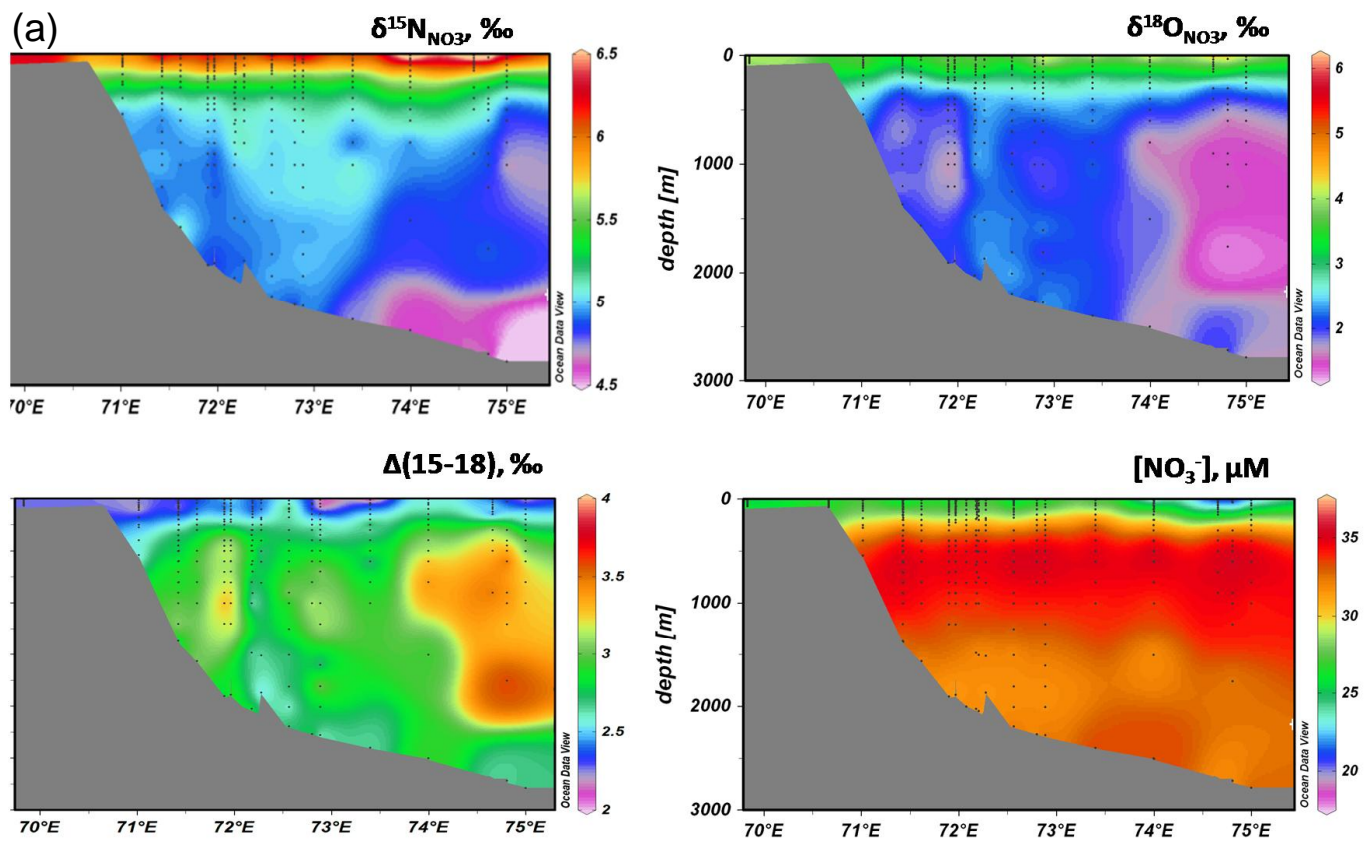

Tpot, ${ }^{\circ} \mathrm{C}$
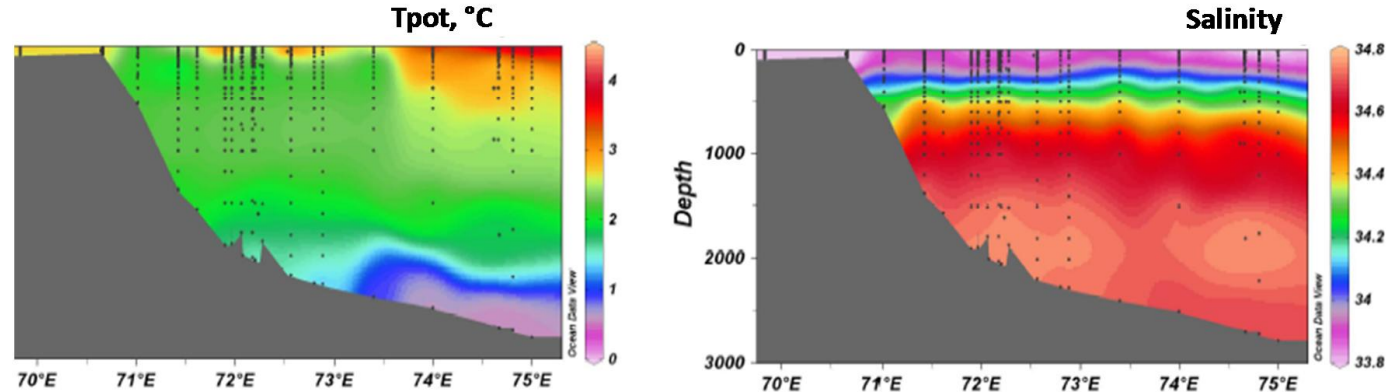

Figure 3. Whole water column distributions of $\delta^{15} \mathrm{~N}_{\mathrm{NO}_{3}}, \delta^{18} \mathrm{O}_{\mathrm{NO}_{3}}, \mathrm{NO}_{3}^{-}, T_{\text {pot }}$ and salinity: (a) west to east section starting on the Kerguelen Plateau and crossing the Polar Front Meander; the Polar Front loop is crossed at about 71.3 and at $74^{\circ}$ E; (b) south to north section along about $72^{\circ}$ E. (ODV-AWI, R. Schlitzer).

waters) underlying UCDW (Fig. 2c). Although $\delta^{18} \mathrm{O}$ slope values for the upper $250 \mathrm{~m}$ (Fig. 4) tend to be smaller than whole water column slopes, they still clearly exceed those for $\delta^{15} \mathrm{~N}_{\mathrm{NO}_{3}}$.

The larger slope values of $\delta^{18} \mathrm{O}$ vs. $\mathrm{LN}\left[\mathrm{NO}_{3}^{-}\right]$regressions compared to those for $\delta^{15} \mathrm{~N}$, at first sight might reflect the fact that the apparent discrimination factors for ${ }^{18} \mathrm{O} /{ }^{16} \mathrm{O}$ and ${ }^{15} \mathrm{~N} /{ }^{14} \mathrm{~N}\left({ }^{15} \varepsilon ;{ }^{18} \varepsilon\right)$ are not similar, as is expected $\left(\varepsilon^{15} / \varepsilon^{18}=1\right)$ in the case of nitrate uptake (and also denitrification, but this is irrelevant for the oxygen-rich environment studied here) being the sole process inducing isotopic fractionation (Granger et al., 2004, 2008; Sigman et al., 2009b). The likeliness that nitrification in subsurface waters as well as in the upper mixed layer is responsible for these observations is developed further below. A further process that could divert the $\varepsilon^{15} / \varepsilon^{18}$ ratio from unity is diazotrophy, evidence of which is discussed by Gonzalez et al. (2014). Dinitrogen fixation would lower nitrate $\delta^{15} \mathrm{~N}$ without affect- ing $\delta^{18} \mathrm{O}$. The $\mathrm{N}_{2}$ fixation rates for the upper $50 \mathrm{~m}$ for the Plateau and R-2 sites reach at most $0.2 \mathrm{mmol} \mathrm{m}^{-2} \mathrm{~d}^{-1}$ (Gonzalez et al., 2014). For the Plateau site this represents only about $1 \%$ of the calculated best fit nitrification rate (see below) of $18 \mathrm{mmol} \mathrm{m}^{-2} \mathrm{~d}^{-1}$. No $\mathrm{N}_{2}$ fixation rates are available for the Meander sites, but assuming that the rate observed at Plateau and R-2 also applies for the Meander site, $\mathrm{N}_{2}$ fixation rate for the Meander would represent some $20 \%$ of the calculated best-fit nitrification rate $\left(1 \mathrm{mmol} \mathrm{m}^{-2} \mathrm{~d}^{-1}\right.$; see below), which is a significant fraction. For the Meander site, however, the nitrification rate itself is poorly constrained (see below), making it difficult to definitively conclude here on the relative significance of $\mathrm{N}_{2}$ fixation and nitrification for that site.

\subsection{Differential behaviour of $\delta^{15} \mathrm{~N}_{\mathrm{NO}_{3}}$ and $\delta^{18} \mathrm{O}_{\mathrm{NO}}$ evidenced from $\Delta(15-18)$}

Differences between the $\delta^{15} \mathrm{~N}_{\mathrm{NO}_{3}}$ and $\delta^{18} \mathrm{O}_{\mathrm{NO}_{3}}$ profiles are highlighted even more when plotting the difference between 

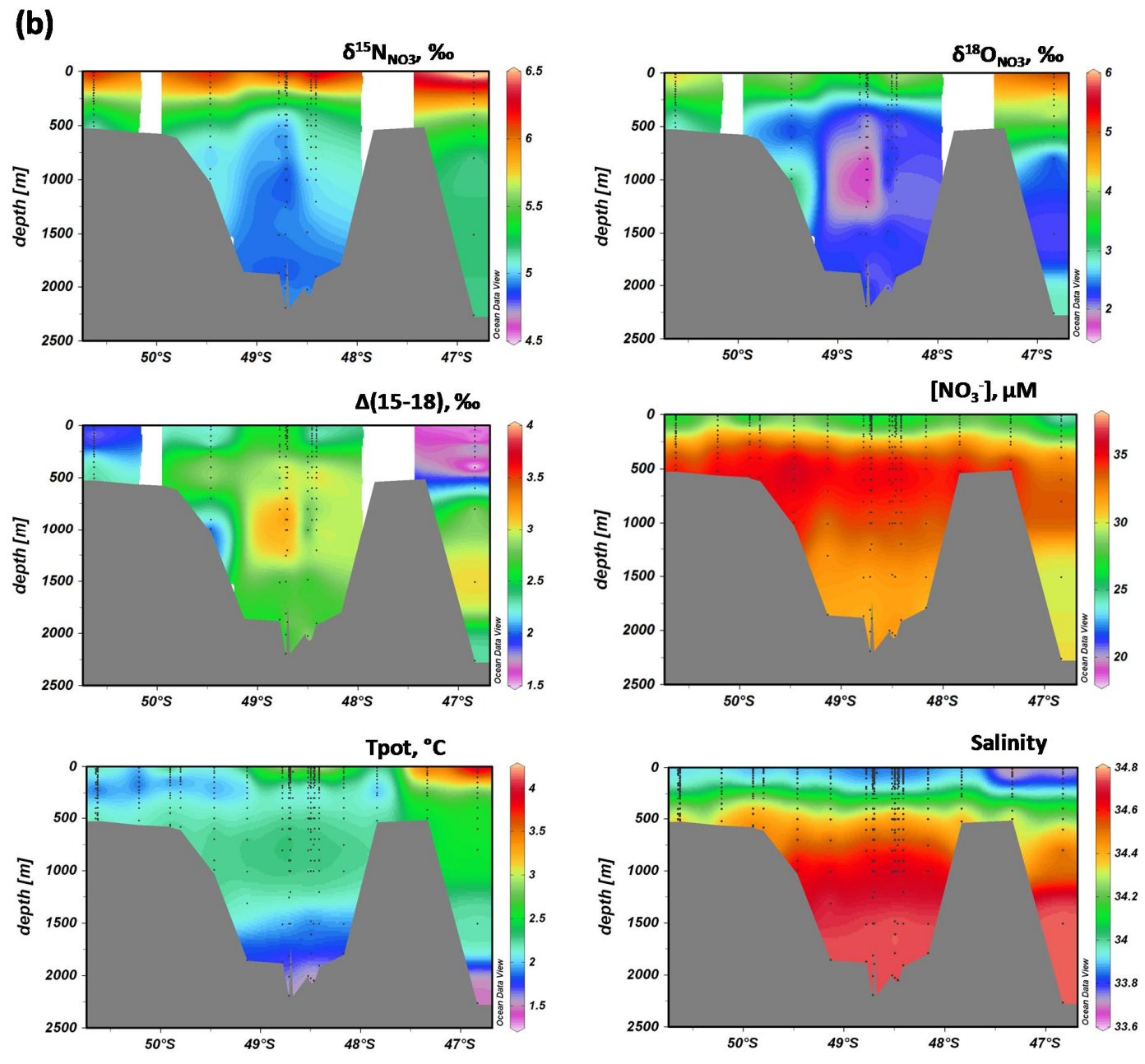

Figure 3. Continued.

these isotopic compositions (i.e. $\delta^{15} \mathrm{~N}_{\mathrm{NO}_{3}}-\delta^{18} \mathrm{O}_{\mathrm{NO}_{3}}=$ $\Delta(15-18)$; see Fig. 2d). A striking feature that appears from the present data set are the consistently low $\Delta(15-18)$ value $(<3 \%$; range $0.8-3)$ in the upper $250 \mathrm{~m}$ for all three areas, reflecting the proportionally stronger enrichment of nitrate in ${ }^{18} \mathrm{O}$ than ${ }^{15} \mathrm{~N}$.

Note that the sole effect of nitrate uptake with similar ${ }^{15} \mathrm{~N} /{ }^{14} \mathrm{~N},{ }^{18} \mathrm{O} /{ }^{16} \mathrm{O}$ discrimination would have left $\Delta(15-$ 18) unchanged (Sigman et al., 2005), which is not the case here. Such a feature of low $\Delta(15-18)$ values $(<3 \%$ ) throughout the surface layer where nitrate concentrations are mostly $\geq 20 \mu \mathrm{M}$, appears characteristic not only for the present spring data set, but also for the summer data obtained during KEOPS 1 (Trull et al., 2008) and has not been reported for other Southern Ocean studies. Rafter et al. (2013) report low values $(2.5-3 \%)$ in subsurface waters $(\sim 100$ $400 \mathrm{~m} ;<25 \mu \mathrm{M} \mathrm{NO}_{3}^{-}$) at latitudes around $50^{\circ} \mathrm{S}$ but these are overlaid with surface waters $\left(<15 \mu \mathrm{M} \mathrm{NO}_{3}^{-}\right)$that have high $\delta^{15} \mathrm{~N}_{\mathrm{NO}_{3}}$ and $\delta^{18} \mathrm{O}_{\mathrm{NO}_{3}}$ values and $\Delta(15-18)$ values of about $3 \%$ (see their Fig. 4). The latter authors describe the low

subsurface $\Delta(15-18)$ values $(2.5-3 \%$ ), as being the result of partial consumption of available nitrate in surface waters, export of low $\delta^{15} \mathrm{~N}-\mathrm{PN}$, and remineralization-nitrification there. Since nitrate N, O cycles are uncoupled and ambient seawater with a $\delta^{18} \mathrm{O}$ close to zero (Archambeau et al., 1998) is the main source of oxygen for this "recycled" nitrate (Sigman et al., 2009b), the latter is relatively more depleted in heavy ${ }^{15} \mathrm{~N}$ isotope than in heavy ${ }^{18} \mathrm{O}$ isotope, and this results in $\Delta(15-18)$ values $<3 \%$, as discussed by Rafter et al. (2013). However, as stated above, in contrast to the results reported by the latter authors for Open Antarctic Zone and Polar Front Zone surface waters (Pacific sector) we observe that the subsurface trend of lowered $\Delta(15-18)$ continues in the upper mixed layer, reaching values as low as $1 \%$. We note that the lower $\Delta(15-18)$ values in the upper $200 \mathrm{~m}$ coincide with higher ammonium and nitrite contents (Fig. 6), possibly reflecting effects of nitrification, which could be either a local or imported condition (see Sect. 4.5).

For the waters between 250 and $1250 \mathrm{~m}$ (upper mesopelagic), which include the UCDW, a number of $\Delta(15-$ 
(a)

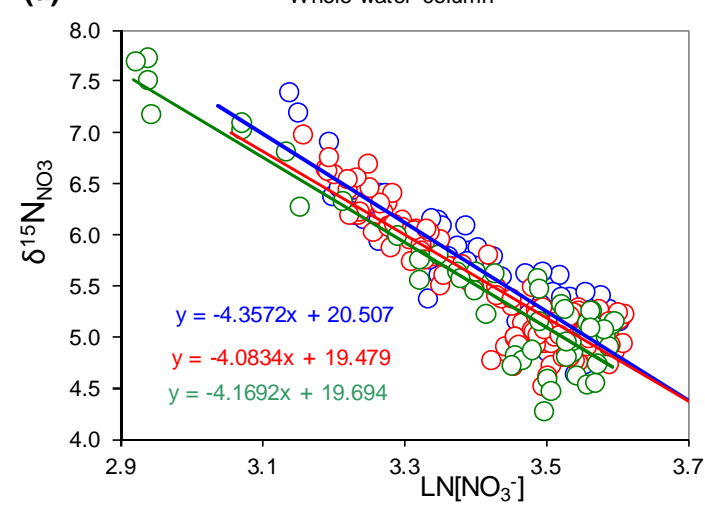

(c)

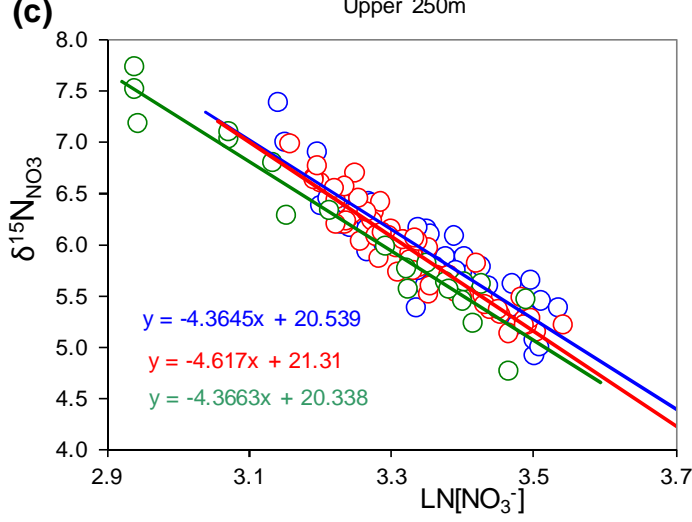

(b)

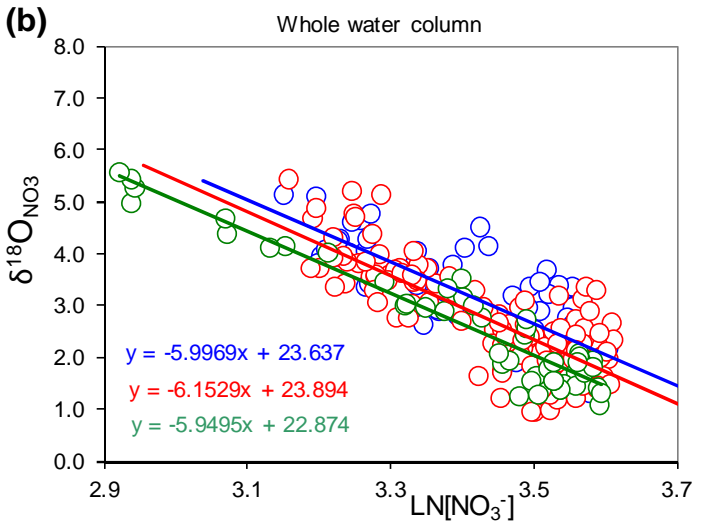

(d)

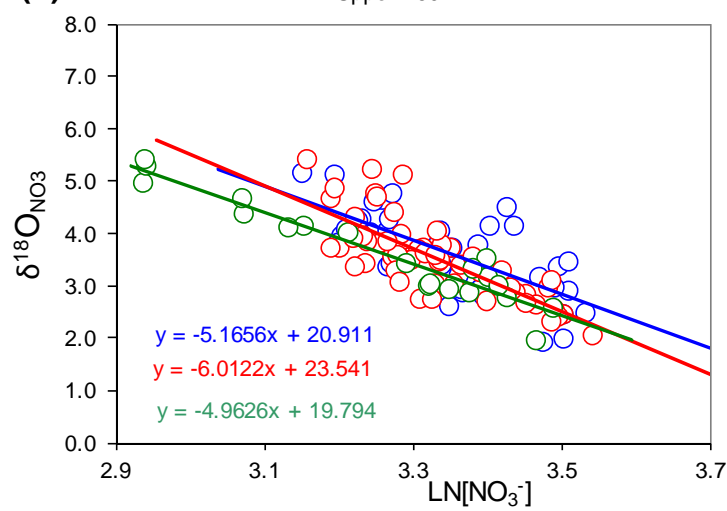

Figure 4. Regressions of $\delta^{15} \mathrm{~N}$ (left) and $\delta^{18} \mathrm{O}$ (right) vs. $\mathrm{LN}\left[\mathrm{NO}_{3}^{-}\right.$]; top row: whole water column; bottom row: upper $250 \mathrm{~m}$; blue circles: plateau stations; red circles: meander stations; green circles: Polar Front and north of Polar Front stations.
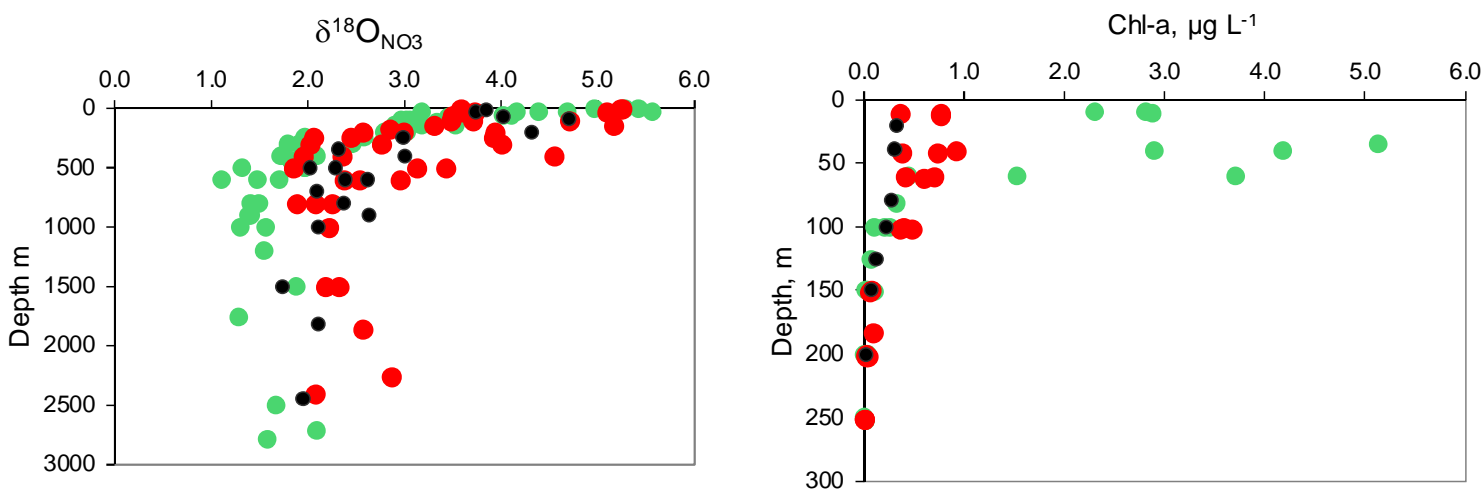

Figure 5. Profiles of $\delta^{18} \mathrm{O}_{\mathrm{NO}_{3}}$ and $\mathrm{Chl} a(\mu \mathrm{g} \mathrm{L}-1$ ) profile for stations underlying the high chlorophyll plume in the vicinity of the Polar Front (green circles; stations TEW-7, TEW-8, F-L) and in the central part of the Polar Front Meander (red circles; stations TNS-6, TNS-1, TEW-6) and the reference station (black circles; station R-2).

18) data points are slightly in excess of $3 \%$ (Fig. 2d) due to low $\delta^{18} \mathrm{O}_{\mathrm{NO}_{3}}$ values (Figs. 2d and 3). From Fig. 3a it appears that this feature concerns mainly stations at the Polar Front east of $74^{\circ} \mathrm{E}$ (stations TEW-7; TEW-8, F-L) underlying high chlorophyll surface waters (Fig. 1), as well as some sites closer to the Kerguelen margin in the west, around $72^{\circ} \mathrm{E}$ (stations E-4W; E-5) (Fig. 3a). The vertical $\delta^{18} \mathrm{O}_{\mathrm{NO}_{3}}$ profiles for these stations show deep $\delta^{18} \mathrm{O}_{\mathrm{NO}_{3}}$ values close to $1.65 \%$ o (i.e. some $0.35 \%$ o lower than the average deep ocean value of $2 \%$ ) (Fig. 5). On the other hand, stations in the low chlorophyll central part of the PF Meander (TEW-5; TEW-6; E4E; TNS-6; E-1), and also north of the PF (TNS-1) and away from the Kerguelen bloom (R-2), show mesopelagic $\delta^{18} \mathrm{O}_{\mathrm{NO}_{3}}$ values close to the deep ocean reference value of $2 \%$. So the 
question arises, what particular process or condition can account for these variations in mesopelagic $\delta^{18} \mathrm{O}_{\mathrm{NO}_{3}}$ values?

A simple calculation shows that the lowered $\delta^{18} \mathrm{O}_{\mathrm{NO}_{3}}$ values cannot be explained by mesopelagic remineralization and nitrification of organic $\mathrm{N}$ exported over the course of a single production season. For the latter process to increase deep ocean nitrate concentrations (taken as $31 \mu \mathrm{M}$ ) to the mesopelagic average value of $34.5 \mu \mathrm{M}$ and to decrease $\delta^{18} \mathrm{O}_{\mathrm{NO}_{3}}$ from the deep ocean value of 2 to $1.65 \%$ o taking a $\delta^{18} \mathrm{O}_{\text {water }}$ of $-0.4 \%$ (Archambeau et al., 1998) and $\delta^{18} \mathrm{O}_{\mathrm{NO}_{3}}$ of nitrification equal to $1.1 \%$ (Sigman et al., $2009 \mathrm{~b}$ ), would require an export and complete remineralization and nitrification of organic nitrogen in the 250-1250 m water column layer of some $20-100 \mathrm{mmol} \mathrm{m}^{-2} \mathrm{~d}^{-1}$ to fit the observed $\left[\mathrm{NO}_{3}^{-}\right]$and $\delta^{18} \mathrm{O}_{\mathrm{NO}_{3}}$, respectively. This is about 10-50 times larger than the export flux from the $150 \mathrm{~m}$ depth horizon estimated via the ${ }^{234} \mathrm{Th}$-deficit approach (average PN flux $=1.9 \mathrm{mmol} \mathrm{m}^{-2} \mathrm{~d}^{-1}$; Planchon et al., 2014). We speculate that the complex recirculation pattern generated by the basin topography and the presence of the PF induces a multiple season integrative effect on the nitrate isotopic signature of the deep water in the gyre structure. The presence of low $\delta^{18} \mathrm{O}_{\mathrm{NO}_{3}}$ values also at some stations located more to the west $\left(72^{\circ} \mathrm{E}\right.$; Fig. 3a) is in agreement with a scenario whereby the low mesopelagic $\delta^{18} \mathrm{O}_{\mathrm{NO}_{3}}$ signature at the Polar Front is entrained with the cyclonic circulation of the PF meander. This signal transfer could be quite fast considering that shipboard measurements by Lowered Acoustic Doppler Current Profiler revealed a strong eastward current along the northern edge of the basin as associated with a cyclonic circulation. This current stretches over the whole water column and reaches a velocity of $25 \mathrm{~cm} \mathrm{~s}^{-1}$ (Y. H. Park, personal communication, 2011). Alternatively we could argue that the low $\delta^{18} \mathrm{O}_{\mathrm{NO}_{3}}$ feature is imported from elsewhere. The mesopelagic waters in the $250-1250 \mathrm{~m}$ range do comprise UCDW waters (i.e. temperature maximum waters above the salinity maximum waters). As discussed by Rafter et al. (2013) these waters carry heavy $\delta^{15} \mathrm{~N}_{\mathrm{NO}_{3}}$ and decreased $\delta^{18} \mathrm{O}_{\mathrm{NO}_{3}}$ isotopic signatures acquired at lower latitudes and resulting from a combination of processes including: (i) partial nitrate assimilation in the surface waters feeding northward-flowing Antarctic Mode and Intermediate Waters (Sigman et al., 2009b) and (ii) flux of partially denitrified waters into surface waters (mainly in the Pacific and Indian oceans) combined with nearly complete consumption of nitrate in the low latitude ocean, yielding high $\delta^{15} \mathrm{~N}$ values for sinking PN (see Sigman et al., 2009a; Rafter et al., 2013). This yields subtropical subsurface waters with high $\delta^{15} \mathrm{~N}_{\mathrm{NO}_{3}}$ and low $\delta^{18} \mathrm{O}_{\mathrm{NO}_{3}}$, and thus high $\Delta(15-18)$ values. These isotopic signatures are again advected southward with deep water and become subsequently incorporated in CDW to join the circumpolar circulation (Rafter et al., 2013) explaining the presence of $\Delta(15-18)$ values exceeding $3 \%$. In the Open Antarctic Zone, CDW upwells and its UCDW branch flows northward to subduct at the Polar Front as SAMW and AAIW (Rafter et al., 2013).

\section{3 $\quad \delta^{15} \mathrm{~N}_{\mathrm{NO}_{3}}$ values in bottom waters}

The low $\delta^{15} \mathrm{~N}_{\mathrm{NO}_{3}}$ values in the cold $\left(\sim 0.5^{\circ} \mathrm{C}\right)$ bottom waters in vicinity of the Polar Front (Fig. 3) may possibly be brought about in the case that partial nitrification takes place in the sediments and feeds isotopically light nitrate to the bottom waters, as has been described for the Bering Sea Shelf by Granger et al. (2011). However, if such a process is also operating here in the Kerguelen area, we would expect to see the effects more marked in waters hugging the slopes surrounding the basin. Indeed, there is some evidence for isotopically light $\mathrm{NO}_{3}^{-}$in the western part of the $\mathrm{W}-\mathrm{E}$ section (Fig. 3a), but clearly, the strongest depletions do occur in waters close to, and underlying, the Polar Front in the eastern part of the W-E section and which are quite remote from the slope regions of the basin. These cold bottom waters are likely of southerly origin, associated with the Fawn Trough Current which transports cold Antarctic waters of eastern Enderby origin (Park et al., 2008) and possibly also partly with Deep Western Boundary Current which is part of the deep cyclonic gyre in the Australian-Antarctic Basin (McCartney and Donohue, 2007; Fukamachi et al., 2010). However, values reported for the Polar Antarctic Zone in the Indian and Australian sectors do not show evidence of deep ocean $\delta^{15} \mathrm{~N}_{\mathrm{NO}_{3}}$ values lower than 5\%o (DiFiore et al., 2009). So it remains uncertain where these low $\delta^{15} \mathrm{~N}_{\mathrm{NO}_{3}}$ signatures in bottom waters underlying the Polar Front area at $74-75^{\circ} \mathrm{E}$ originate from.

In the next sections we focus on the conditions in the upper water column where our observations provide evidence of significant nitrification.

\subsection{Co-variation of $\delta^{15} \mathrm{~N}_{\mathrm{NO}_{3}}-\delta^{18} \mathrm{O}_{\mathrm{NO}_{3}}$}

Figure 7 shows the regressions of $\delta^{18} \mathrm{O}_{\mathrm{NO}_{3}}$ vs. $\delta^{15} \mathrm{~N}_{\mathrm{NO}_{3}}$ for the Plateau, Meander and PF areas. As expected from the discussions above, the regression slopes for whole water column are larger than 1 (they vary between 1.4 and 1.5 , for PF and Plateau areas, respectively). The black line in Fig. 7 reflects the expected regression in case discrimination during nitrate uptake is similar for ${ }^{18} \mathrm{O} /{ }^{16} \mathrm{O}$ and ${ }^{15} \mathrm{~N} /{ }^{14} \mathrm{~N}$ and acts upon a nitrate source reservoir that has a deep water isotopic signature (i.e. $\delta^{15} \mathrm{~N}_{\mathrm{NO}_{3}}=5 \%$ and $\delta^{18} \mathrm{O}_{\mathrm{NO}_{3}}=2 \%$ ). When focusing on the upper $250 \mathrm{~m}$ we note that slope values decrease and come close to 1 for the PF area (slope $=1.14$ ), while they are close to 1.3 for Plateau and Meander sites (Fig. 7). For all three areas, it is clear, however, that data points mostly fall above the expected regression. This condition is also clearly reflected in the $\Delta(15-18)$ values which on average fall below $2.5 \%$ for the upper $200 \mathrm{~m}$ of water column (see Fig. 2).

Figure 8 also shows the summer data obtained during KEOPS 1 (Trull et al., 2008) superposed on the present 
KEOPS 2 spring data. This comparison is limited to the upper $250 \mathrm{~m}$ of the water column, i.e. the depth range analysed during KEOPS 1 (Trull et al., 2008). The summer data overlap tightly with the spring data but also sit above the $1: 1$ line, defined above, but in contrast to spring, summer shows a slope value close to 1 (0.98). However, a closer look reveals that the deep summer samples have slightly more elevated $\delta^{18} \mathrm{O}_{\mathrm{NO}_{3}}$ values, tilting the regression and thereby decreasing the slope value. These more elevated subsurface $\delta^{18} \mathrm{O}_{\mathrm{NO}_{3}}$ values may reflect the effect of subsurface nitrification in an area of partial surface nitrate assimilation (Rafter et al., 2013; Sigman et al., 2009b). When focusing on the mixed layer depth, the slopes of the $\delta^{18} \mathrm{O}_{\mathrm{NO}_{3}}$ vs. $\delta^{15} \mathrm{~N}_{\mathrm{NO}_{3}}$ regressions become even steeper for the Plateau (up to 1.65) and Meander areas and for the KEOPS 1 data set (Fig. 7), but not for the PF area. Thus, within the upper $250 \mathrm{~m}$ and even more so in the upper mixed layer, the variations of $\delta^{18} \mathrm{O}_{\mathrm{NO}_{3}}$ values clearly exceed those for corresponding $\delta^{15} \mathrm{~N}_{\mathrm{NO}_{3}}$ values. Such a condition may result from the remineralization-nitrification of organic nitrogen (Sigman et al., 2009b, DiFiore et al., 2009). Also, the absence of a clear differentiation between summer (KEOPS 1) and spring (KEOPS 2) conditions (Fig. 7; we would expect to see the summer condition further up the line with higher $\delta^{15} \mathrm{~N}$ and $\delta^{18} \mathrm{O}$ values) is quite puzzling, and may reflect the fact that the nitrate consumed is being largely replenished from remineralization coupled to nitrification, thereby dampening the enrichment of ${ }^{15} \mathrm{~N}$ due to uptake (but enhancing the ${ }^{18} \mathrm{O}$ enrichment). We also note that the average deficit of silicic acid and nitrate in the mixed layer vs. the winter values in underlying $T_{\min }$ waters are systematically $\gg 1$ (up to 4) for the whole area, while $\mathrm{Si}(\mathrm{OH})_{4} / \mathrm{NO}_{3}^{-}$ uptake ratios are generally close to 1 (0.74 to 1.51$)$ for the Plateau and Meander areas, consistent with iron-replete conditions there (Closset et al., 2014; Cavagna et al., 2014). The larger deficit of silicic acid compared to nitrate could thus partly result from shallow recycling of nitrogen. In fact nitrate contents stay relatively high throughout the growth season and KEOPS 1 summer nitrate values remain generally in excess of $20 \mu \mathrm{M}$ (Trull et al., 2008), while summer silicic acid concentrations run low to near depletion, despite the $\mathrm{Si}(\mathrm{OH})_{4} / \mathrm{NO}_{3}^{-}$uptake ratio being close to 1 (Mosseri et al., 2008). This is further evidence for significant nitrification in the upper mixed layer. The combined effect of nitrate uptake and nitrification in the euphotic zone will result in decoupling the $\delta^{15} \mathrm{~N}_{\mathrm{NO}_{3}}$ and $\delta^{18} \mathrm{O}_{\mathrm{NO}_{3}}$ signals, thereby decreasing their average deep ocean difference of $3 \%$.

The question can be raised, to what extent is this a local or imported condition from an upstream area? At the HNLC reference station, located upstream of the Kerguelen Plateau and Meander areas the upper mixed layer values of $\delta^{15} \mathrm{~N}$ and $\delta^{18} \mathrm{O}$ are increased by about $1.2 \%$ and $2 \%$, respectively, relative to local deep waters (Fig. 2). This results in decreased $\Delta(15-18)$ values (average value upper $100 \mathrm{~m}=2.25 \%$ o), which are similar to values for the Meander $(\Delta(15-18)=2.39 \pm 0.44 \%)$, PF $(\Delta(15-$
$18)=2.44 \pm 0.28 \%$ ) and also Plateau sites sampled during the earlier part of the study period (A3-1; E-4W; TNS-8; TEW-4; $\Delta(15-18)=2.51 \pm 0.38 \%$ o). Such values, however, are larger than those for Plateau sites sampled toward the end of the study period (E-4W-2 and A3-2; average $\Delta(15-$ $18)=1.79 \pm 0.12 \%$ ) , adding evidence for ongoing nitrification during this early bloom phase, at least above the Plateau. Meander and Polar Front sites on the contrary do not show such evidence, as their upper ocean $\Delta(15-18)$ values do not differentiate from the value at the HNLC reference station.

Nitrification could possibly occur at the shelf sediment water column interface, as reported for the low nitrate Bering Sea shelf, characterized by high $\mathrm{NH}_{4}^{+}$levels (Granger et al., $2011,2013)$. For instance, at the shallow $(<100 \mathrm{~m})$ TEW1 shelf station (see Fig. 6a) ammonium contents are enhanced (up to $1.1 \mu \mathrm{M}$ ) close to the seafloor. We note, however, that $\Delta(15-18)$ values are relatively large, averaging $2.3 \%$ (Fig. 6a; Table A1), a condition that is not indicative of significant nitrification. Furthermore, the shallow TEW1 station is located north of the Polar Front, and surface waters advected from this shallow shelf area flow northnortheast, staying north of the PF (see surface water flow lines in Fig. 1b), away from A3. Except for this station TEW1 we do not see evidence for nitrification at the sediment water column boundary layer elsewhere above the Kerguelen Plateau, though we have no data for the shallow water column $(<100 \mathrm{~m})$ close to Heard Island located further south on the Plateau, some $400 \mathrm{Km}$ upstream of site A3 (Fig. 1a). During KEOPS 1 (summer 2005) $\mathrm{NH}_{4}^{+}$and $\mathrm{NO}_{2}^{-}$concentrations at the $\mathrm{C} 1$ site close to Heard Island reached up to 0.7 and $0.4 \mu \mathrm{M}$, respectively and a single nitrate isotopic measurement for the $\mathrm{C} 1$ site gave a $\Delta(15-18)$ value of $2.13 \%$ o (Trull et al., 2008) - so conditions similar to those observed here for site TEW-1. Especially the large $\Delta(15-18)$ values $(>2 \%$ ) observed for these two shallow $(<100 \mathrm{~m})$ plateau sites make it unlikely that sediment boundary layer nitrification is a source of nitrate to the mixed layer above the main Kerguelen Plateau area south of the Polar Front. In the next section we evaluate the strength of a possible nitrification in the surface layers.

\subsection{Calculating the temporal evolution of $\delta^{15} \mathrm{~N}_{\mathrm{NO}_{3}}$ and $\delta^{18} \mathrm{O}_{\mathrm{NO}_{3}}$ in the surface mixed layer}

The similarity of the ranges of upper ocean nitrate isotopic compositions during early (KEOPS 1 ) and late (KEOPS 2) season (Fig. 7) raises the question of whether the Kerguelen system had already reached some steady-state condition for nitrogen cycling early in the season, with nitrate consumption being significantly balanced by remineralization combined with nitrification. However, earlier studies suggest that the evidence for significant euphotic zone nitrification in Southern Ocean surface waters is weak (Olson, 1981a; Bianchi et al., 1997; Trull et al., 2008; DiFiore et al., 2009). To resolve this apparent controversy we will estimate the 

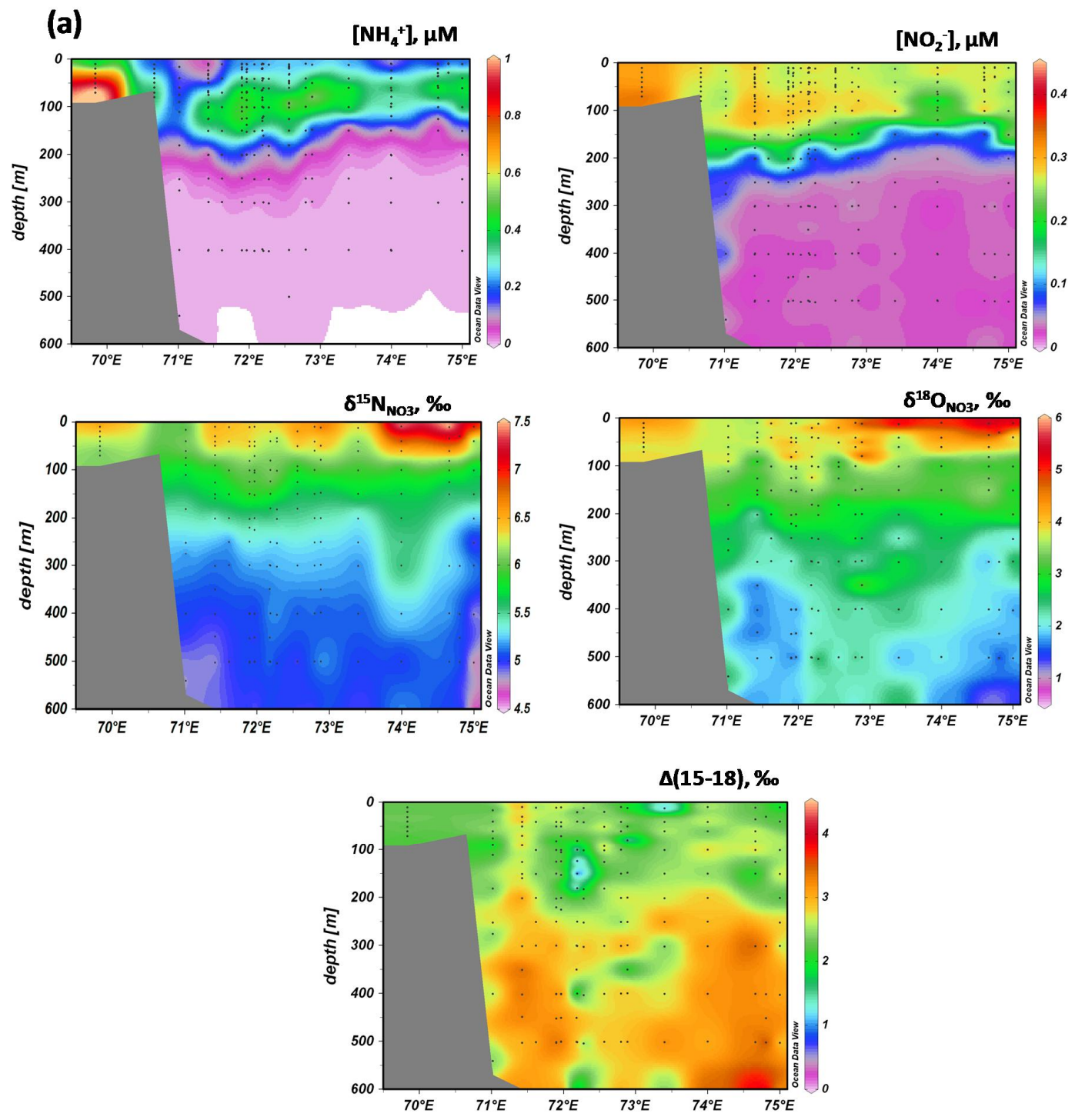

Figure 6. Sections of $\mathrm{NH}_{4}^{+}, \mathrm{NO}_{2}^{-}, \delta^{15} \mathrm{~N}_{\mathrm{NO}_{3}}, \delta^{18} \mathrm{O}_{\mathrm{NO}_{3}}$ and $\Delta(15-18)$ in the upper $600 \mathrm{~m}$ of water column; (a) West to East section; (b) South to north section. $\mathrm{NH}_{4}^{+}$and $\mathrm{NO}_{2}^{-}$data are from Blain et al. (2015). (ODV-AWI, R. Schlitzer).

strength of nitrification in the upper mixed layer. We apply a mass balance approach for both $\delta^{15} \mathrm{~N}_{\mathrm{NO}_{3}}$ and $\delta^{18} \mathrm{O}_{\mathrm{NO}_{3}}$ in the mixed layer of Plateau and Meander stations where data on temporal evolution are available. We take advantage of the fact that nitrate and ammonium uptake rates were measured during KEOPS 2 (Cavagna et al., 2014) and also that values of isotopic composition of suspended and sinking material are available (Trull et al., 2015; Dehairs, unpublished results). Note that the model calculations presented here cover a limited length of growth period (about 1 month). More complex model calculations describing the evolution nitrification over the full growth season are presented elsewhere (Fripiat et al., 2015).

We take the upper $100 \mathrm{~m}$ nitrate conditions observed during the earliest visit to the Plateau and Meander as the ini- tial conditions (i.e. conditions for stations A3-1 and TNS-6 respectively). Euphotic zone (0.01\% PAR; 57 to $137 \mathrm{~m}$ deep) integrated nitrate uptake rates reported by Cavagna et al. (2014) show an increase by some $30 \%$ for the Meander region (Stations E-1, E-3, E-4E and E-5; 27 day period). For the Plateau region only two $\mathrm{N}$-uptake profiles (stations E-4W; A3-2) were measured - apart by just 4 days. Nitrate uptake for the Meander sites are on average $12.4 \pm 2.2 \mathrm{mmol} \mathrm{m}^{-2} \mathrm{~d}^{-1}(n=4)$ while for the Plateau sites they are $36 \pm 4.7(n=2)$. Ammonium uptake rates are $6.6 \pm 1.4 \mathrm{mmol} \mathrm{m}^{-2} \mathrm{~d}^{-1}(n=4)$ and $6.2 \pm 1.9(n=2)$ for Meander and Plateau sites, respectively. Using these average nitrate uptake rates we calculate the nitrate concentrations (called residual nitrate) that would be present in the upper $100 \mathrm{~m}$ at the end of the observation period in the case 
(b)
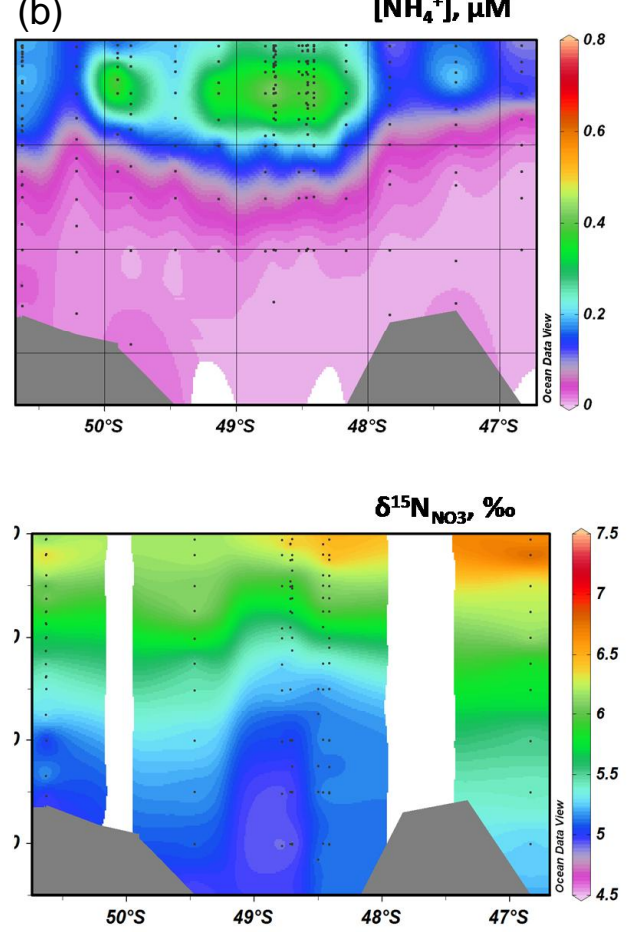
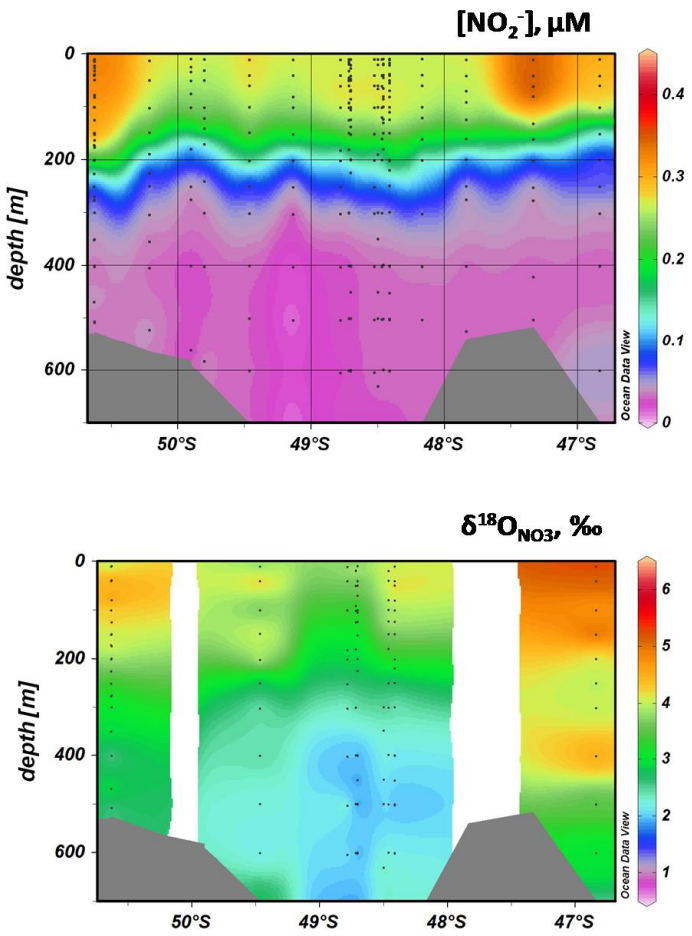

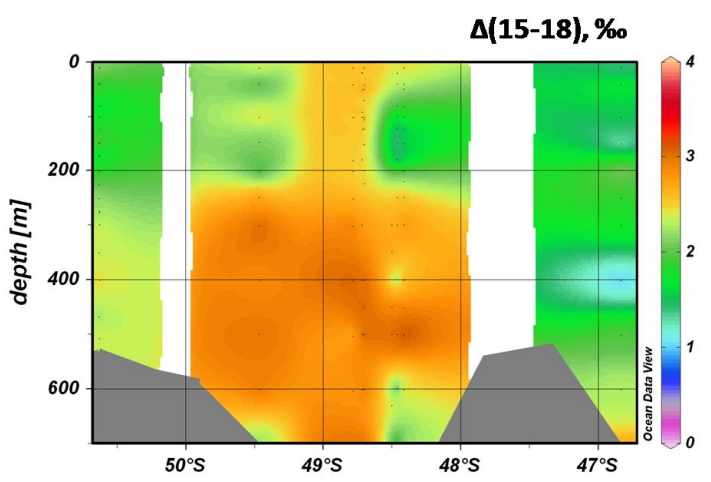

Figure 6. Continued.

that uptake is the sole process affecting the nitrate concentration. Nitrate concentrations at stations A3-1 (Plateau) and TNS-6 (Meander) were considered to represent the initial conditions, whereas concentrations at stations A3-2 (Plateau) and station E-5 (Meander), visited 27 days after A3-1 and TNS-6, respectively, represent the conditions at the end of the observation period. Residual nitrate values are slightly $\left(\Delta\left[\mathrm{NO}_{3}^{-}\right]=1.8 \mu \mathrm{M}=6 \%\right.$; Meander $)$ to significantly lower $\left(\Delta\left[\mathrm{NO}_{3}^{-}\right]=4.1 \mu \mathrm{M}=25 \%\right.$; Plateau) than measured values (see Table 3). The isotopic composition of the residual nitrate is then calculated from the estimated fraction of nitrate remaining, using a discrimination of $5 \%$ or both ${ }^{15} \mathrm{~N} /{ }^{14} \mathrm{~N}$ and ${ }^{18} \mathrm{O} /{ }^{16} \mathrm{O}$ (Sigman et al.,1999; DiFiore et al., 2010) and considering that the surface mixed layer operates as a closed system (Rayleigh fractionation applies). The calculated isotopic compositions of the residual nitrate are heavier than the measured ones. The differences between calculated and observed isotopic values are: for $\delta^{15} \mathrm{~N} 0.22$ and $1.45 \%$ and for $\delta^{18} \mathrm{O}, 0.10$ and $0.98 \%$ o for Meander and Plateau areas, respectively. For the Meander differences are small (close to the analytical precision), showing little evidence for nitrification. For the Plateau area, on the contrary, the larger offset points to the occurrence of significant nitrate input from local nitrification and upwelling.

The isotope effects associated with nitrification are taken as follows, assuming a steady state between the production and consumption of both ammonium and nitrite 
(a)

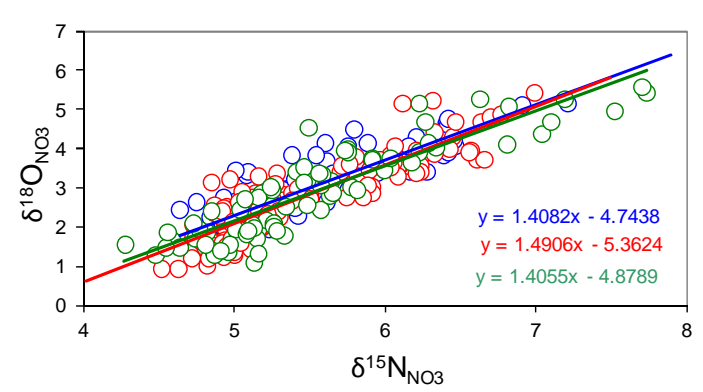

(b)

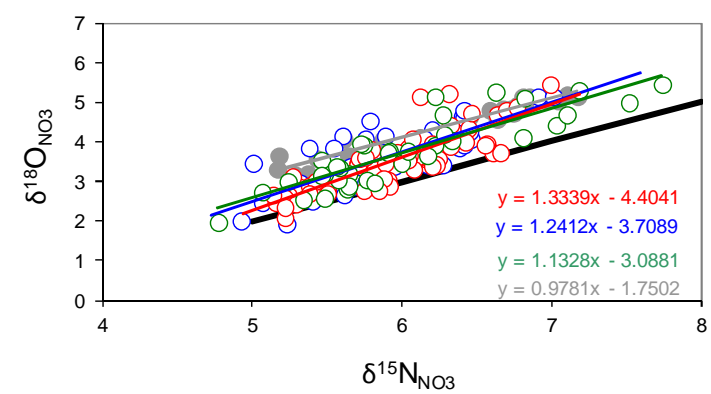

(c)

Mixed Layer

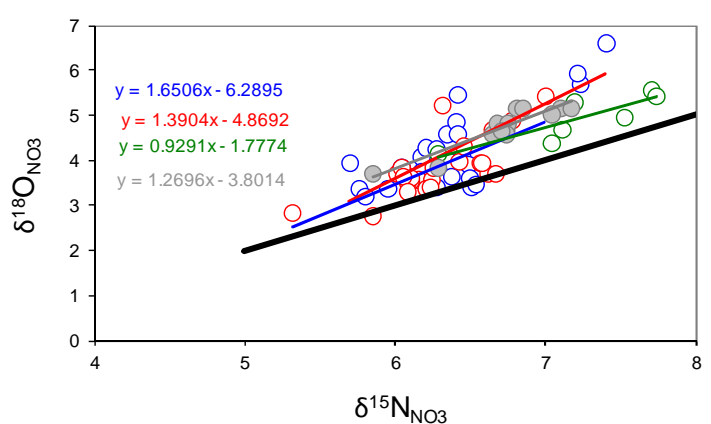

Figure 7. $\delta^{18} \mathrm{O}_{\mathrm{NO}_{3}}$ vs. $\delta^{15} \mathrm{~N}_{\mathrm{NO}_{3}}$; blue: Plateau; red: Meander; green: Polar Front and north of PF: (a) whole water column; (b) upper $250 \mathrm{~m}$; (c) mixed layer; grey circles represent the late season Plateau values recorded during KEOPS 1 (Trull et al., 2008); the black line with slope $=1$ represents the evolution of reference deep water nitrate with $\delta{ }^{15} \mathrm{~N}_{\mathrm{NO}_{3}}=5 \%$ and $\delta^{18} \mathrm{O}_{\mathrm{NO}_{3}}=2 \%$ in the case that the ${ }^{15} \mathrm{~N} /{ }^{14} \mathrm{~N}$ and ${ }^{18} \mathrm{O} /{ }^{16} \mathrm{O}$ fractionation factors are similar.

(e.g., Fripiat et al., 2014):

For $\delta^{15} \mathrm{~N}_{\mathrm{NO}_{3}}:$ Nitrif.[ $\left[\delta^{15} \mathrm{~N}_{\mathrm{PN}}-\varepsilon_{\mathrm{R}}+\right.$

$\left.x\left(\varepsilon_{\mathrm{NH} 4 \mathrm{u}}-\varepsilon_{\mathrm{AmO}}\right)+y\left(\varepsilon_{\mathrm{NiU}}-\varepsilon_{\mathrm{NiO}}\right)\right]$

For $\delta^{18} \mathrm{O}_{\mathrm{NO}_{3}}$ : Nitrif. $\left(\delta^{18} \mathrm{O}_{\mathrm{H}_{2} \mathrm{O}}+1.1\right)$

(Sigman et al., 2009b)

with Nitrif $=$ the nitrification rate, $\delta^{15} \mathrm{~N}_{\mathrm{PN}}=$ the $\mathrm{N}$ isotopic composition of suspended material $\left(1.74 \%\right.$ ) ; $\delta^{18} \mathrm{O}_{\mathrm{H}_{2} \mathrm{O}}=$ the oxygen isotopic composition of ambient water; $\varepsilon_{\mathrm{R}}=$ the discrimination during remineralization $(2 \% o) ; \varepsilon_{\mathrm{NH} 4 \mathrm{U}}=$ the isotope discrimination during $\mathrm{NH}_{4}^{+}$uptake $(5 \%) ; \varepsilon_{\mathrm{AMO}}=$ the discrimination during $\mathrm{NH}_{4}^{+}$oxidation $\left(15 \% \circ ; \varepsilon_{\mathrm{NiU}}=\right.$ the discrimination during nitrite uptake $(1 \%) ; \varepsilon_{\mathrm{NiO}}=$ the discrimination during nitrite oxidation $(-12.5 \%) ; x=$ the fractional yield of ammonium uptake relative to ammonium remineralization (with $\mathrm{NH}_{4}^{+}$remin. $=\mathrm{AmU}+\mathrm{AmO}$ ) and $\mathrm{y}=$ the fractional yield of nitrite uptake relative to ammonium oxidation (with $\mathrm{AmO}=\mathrm{NiU}+\mathrm{NiO}$ ). Table 2 gives the selected values for the different discrimination factors as taken from the literature.

The theoretical in situ nitrate isotopic values at the end of the observation period are considered to result from the weighted impact of uptake, nitrification and upwelling and were calculated as follows:

$\delta^{15} \mathrm{~N}_{\mathrm{NO}_{3}}=$

$\frac{\text { Uptake }\left(\delta^{15} \mathrm{~N}_{\mathrm{NO}_{3}}-\varepsilon_{\mathrm{NaU}} \mathrm{Lnf}\right)}{\text { Uptake+Nitrif+Upwelling }}+$

$\frac{\operatorname{Nitrif}\left[\delta^{15} \mathrm{~N}_{\mathrm{PN}}-\varepsilon_{\mathrm{R}}+x\left(\varepsilon_{\mathrm{NH} 4 \mathrm{U}}-\varepsilon_{\mathrm{AmO} O}\right)+y\left(\varepsilon_{\mathrm{NiU}}-\varepsilon_{\mathrm{NiO}}\right)\right]+\mathrm{Upw}\left(\delta^{15} \mathrm{~N}_{\mathrm{NO} 3 \mathrm{~T} \text { min }}\right)}{\text { Uptake+Nitriff Upwelling }}$

and

$\delta^{18} \mathrm{O}_{\mathrm{NO}_{3}}=$

$\frac{\text { Uptake }\left(\delta^{18} \mathrm{O}_{\mathrm{NO}_{3}}-\varepsilon_{\mathrm{NaU}} \mathrm{Lnf}\right)}{\text { Uptake+Nitrif+Upwelling }}+$

$\frac{\operatorname{Nitrif}\left(\delta^{18} \mathrm{O}_{\mathrm{H}_{2} \mathrm{O}}\right)+\mathrm{Upw}\left(\delta^{18} \mathrm{O}_{\mathrm{NO} 3 \mathrm{Tmin}}\right)}{\text { Uptake+Nitrif }+ \text { Upwelling }}$

With the different $\varepsilon$ values = the isotopic discriminations; $\delta^{15} \mathrm{~N}_{\mathrm{NO} 3 \mathrm{Tmin}}$ and $\delta^{18} \mathrm{O}_{\mathrm{NO} 3 \mathrm{Tmin}}=$ isotopic composition for the subsurface temperature minimum waters $(\varepsilon$ and $\delta$ values are given in Table 2); $f=$ fraction of remaining nitrate; $x$ and $y$, as defined above; Uptake $=$ nitrate uptake rate; $\mathrm{Ni}$ trif $=$ nitrification rate; $\mathrm{Upw}=$ rate of vertical advection of nitrate. 
Table 2. Considered isotopic discrimination factors for model calculations.

\begin{tabular}{|c|c|c|c|}
\hline Parameter, process & $\delta^{18} \mathrm{O}, \%$ & $\varepsilon^{15} ; \varepsilon^{18}, \%$ & References \\
\hline$\delta^{18} \mathrm{O}-\mathrm{H}_{2} \mathrm{O}$ & -0.4 & & Archambeau et al. (1998) \\
\hline Remineralization & & $0-2$ & Kendall (1998); Knapp et al. (2011); Möbius (2013) \\
\hline $\mathrm{NO}_{3}$ uptake & & $4.5-6.3$ & Waser et al. (1998); Granger et al. (2010); DiFiore et al. (2010) \\
\hline $\mathrm{NH}_{4}$ uptake & & $0-5^{*}$ & $\begin{array}{l}\text { Hoch et al. (1992); Fogel and Cifuentes (1993); } \\
\text { Pennock et al. (1996); Waser et al. (1999) }\end{array}$ \\
\hline $\mathrm{NH}_{4}$ oxidation & & 15 & Casciotti et al. (2003); DiFiore et al. (2009) \\
\hline $\mathrm{NO}_{2}$ oxidation & & -12 to -13 & Casciotti (2009); Buchwald and Casciotti (2010) \\
\hline $\mathrm{NO}_{2}$ Uptake & & $0-1$ & Waser et al. (1998) \\
\hline
\end{tabular}

* For low ammonium concentrations $(<10 \mu \mathrm{M})$.

Table 3. Plateau and Meander sites: Observed initial and final conditions of nitrate concentration and isotopic composition; Observed nitrate and ammonium uptake rates (from Cavagna et al., 2014); Calculated nitrification, nitrite uptake, nitrate upwelling rates required to explain the observed nitrate isotopic composition and nitrate concentration at the end of the considered growth period.

\begin{tabular}{|c|c|c|c|c|c|c|}
\hline & $\begin{array}{r}{\left[\mathrm{NO}_{3}^{-}\right]} \\
\mu \mathrm{M}\end{array}$ & $\begin{array}{r}\delta^{15} \mathrm{~N}_{\mathrm{NO}_{3}} \\
\% \circ\end{array}$ & $\begin{array}{r}\delta^{18} \mathrm{O}_{\mathrm{NO}_{3}} \\
\% \circ\end{array}$ & $\begin{array}{l}\text { Measured flux } \\
\mathrm{mmol} \mathrm{m}^{-2} \mathrm{~d}^{-1}\end{array}$ & $\begin{array}{l}\text { Best fit (min. }- \text { max.) } \\
\text { mmol m}{ }^{-2} \mathrm{~d}^{-1}\end{array}$ & $\begin{array}{l}\text { Best fit (min. - max.); fixed upwelling }{ }^{\mathrm{b}} \\
\mathrm{mmol} \mathrm{m}^{-2} \mathrm{~d}^{-1}\end{array}$ \\
\hline \multicolumn{7}{|l|}{ Plateau } \\
\hline Upwelling water & 29.9 & 5.74 & 3.31 & & & \\
\hline Average condition in upper $100 \mathrm{~m}$ (A3-1); $T_{0}$ & 29.3 & 5.85 & 3.40 & & & \\
\hline Average condition in upper $100 \mathrm{~m}$ (A3-2); $T_{\text {end }}$ & 25.8 & 6.42 & 4.46 & & & \\
\hline $\mathrm{NO}_{3}^{-}$uptake & & & & $36.5 \pm 4.7^{\mathrm{a}}$ & & \\
\hline $\mathrm{NH}_{4}^{+}$uptake & & & & $6.2 \pm 1.9^{\mathrm{a}}$ & & \\
\hline Calculated: uptake only (Rayleigh) & 19.4 & 7.92 & 5.47 & & & \\
\hline Calculated: nitrification & & & & & $17.4 ;(6-27)$ & $16.2 ;(10-22)$ \\
\hline Calculated: $\mathrm{NO}_{3}^{-}$upwelling & & & & & $6.2 ;(0-24)$ & 7.4 \\
\hline Calculated: $\mathrm{NO}_{2}^{-}$uptake & & & & & $6.1 ;(0-17)$ & $5.6 ;(0-14)$ \\
\hline \multicolumn{7}{|l|}{ Polar Front Meander } \\
\hline Upwelling water & 31.6 & 5.32 & 2.85 & & & \\
\hline Average condition in upper $100 \mathrm{~m}$ (TNS-6); T0 & 27.4 & 6.17 & 3.74 & & & \\
\hline Average condition in upper $100 \mathrm{~m}$ (E-5); Tend & 25.6 & 6.62 & 4.33 & & & \\
\hline $\mathrm{NO}_{3}^{-}$uptake & & & & $12.4 \pm 2.2^{\mathrm{a}}$ & & \\
\hline $\mathrm{NH}_{4}^{+}$uptake & & & & $6.6 \pm 1.4^{\mathrm{a}}$ & & \\
\hline Calculated: uptake only (Rayleigh) & 24.0 & 6.73 & 4.33 & & & \\
\hline Calculated: nitrification & & & & & $1.7 ;(0-11)$ & $1.3 ;(0-6)$ \\
\hline Calculated: $\mathrm{NO}_{3}^{-}$upwelling & & & & & $4.0 ;(0-11)$ & 7.4 \\
\hline Calculated: $\mathrm{NO}_{2}^{-}$uptake & & & & & 0 & 0 \\
\hline
\end{tabular}

${ }^{a}$ Average rates from Cavagna et al. (2014). ${ }^{b}$ Nitrate upwelling fixed at $7.4 \mathrm{mmol} \mathrm{m}^{-2} \mathrm{~d}^{-1}$, based on the Ekman pumping velocity in Gille et al. (2014).

The best fit between observed and calculated isotopic compositions is searched using an optimization scheme with nitrification, upwelling from subsurface waters $\left(T_{\min }\right.$ waters at 100 to $150 \mathrm{~m}$ depth), $\mathrm{NH}_{4}^{+}$oxidation and $\mathrm{NO}_{2}^{-}$uptake as adjustable variables.

The matching of observed and calculated nitrate draw down and the matching of $\mathrm{NH}_{4}^{+}$oxidation with $\mathrm{NO}_{2}^{-}$uptake + nitrification are imposed constraints. The bestfit calculations yield nitrification rates of $1.7 \pm 2.3$ and $17.4 \pm 4.1 \mathrm{mmol} \mathrm{m}^{-2} \mathrm{~d}^{-1}$ for Meander and Plateau, respectively (Table 3). Best-fit values are 0 and $5.5 \mathrm{mmol} \mathrm{m}^{-2} \mathrm{~d}^{-1}$ for $\mathrm{NO}_{2}^{-}$uptake and 4.0 and $6.1 \mathrm{mmol} \mathrm{m}^{-2} \mathrm{~d}^{-1}$ for $\mathrm{NO}_{3}^{-}$upwelling, for Meander and Plateau sites respectively (Table 3). We note that the values for nitrate upwelling are quite similar to the value of $7.4 \mathrm{mmol} \mathrm{m}^{-2} \mathrm{~d}^{-1}$ we calculate, as based on an Ekman pumping velocity of $3 \times 10^{-6} \mathrm{~m} \mathrm{~s}^{-1}$ for the stud- ied KEOPS 2 area, reported by Gille et al. (2014), and an average subsurface $(150 \mathrm{~m}) \mathrm{NO}_{3}^{-}$concentration of $28.5 \mu \mathrm{M}$. In the case that the $\mathrm{NO}_{3}^{-}$upwelling rate is fixed and set equal to the calculated value of $7.4 \mathrm{mmol} \mathrm{m}^{-2} \mathrm{~d}^{-1}$ based on the Ekman pumping velocity, the best-fit nitrification rates are slightly smaller but more constrained with values of $1.3 \pm 1.2$ and $16.2 \pm 2.4 \mathrm{mmol} \mathrm{m}^{-2} \mathrm{~d}^{-1}$, for Meander and Plateau, respectively. For the Meander site the evidence for nitrification is poor, in agreement with the fact that surface water $\Delta(15$ 18) values remain small and quite constant over the 1-month period of observation and are similar to those for the HNLC R-2 reference station. We also verified the effect of nitrite presence on these calculations. Indeed, Rafter et al. (2013) report a lowering of the true nitrate $\delta^{15} \mathrm{~N}$ and $\delta^{18} \mathrm{O}$ compositions by 0.4 and $0.2 \%$, respectively, in the case that nitrite contents amount to some $0.8 \%$ of the nitrate content, which 
is the case here (see also Sect. 2.2). It appears that nitrification rates above the Plateau would be reduced by at most $7 \%$ due to unaccounted for nitrite.

We performed a sensitivity test to verify the range (minimum-maximum) of nitrification, nitrite uptake and nitrate upwelling rates, taking into account the measurement errors on isotopic compositions (as given in Sect. 2) and the observed variability on nitrate and ammonium uptake rates. It appears for the Meander site that the min-max range of possible nitrification rates reaches from 0 to $11 \mathrm{mmol} \mathrm{m}^{-2} \mathrm{~d}^{-1}$, a range which narrows from 0 to $4 \mathrm{mmol} \mathrm{m}^{-2} \mathrm{~d}^{-1}$ in the case that $\mathrm{NO}_{3}^{-}$upwelling is kept fixed. The situation is quite different for the Plateau site where the min-max range of nitrification reaches from 6 to $27 \mathrm{mmol} \mathrm{m}^{-2} \mathrm{~d}^{-1}$ which narrows down from 10 to $22 \mathrm{mmol} \mathrm{m}^{-2} \mathrm{~d}^{-1}$ when upwelling is kept fixed. From this we conclude for the Plateau area significant surface layer nitrification needs to be invoked to explain the observed nitrate isotopic compositions and which may represent as much as $47 \%$ of the nitrate uptake. For the Meander the evidence for nitrification is poor.

The conditions leading to the high upper ocean nitrification above the Plateau are believed to be related to the depth range of the euphotic layer and the mixed layer. Above the Plateau the euphotic layer $(0.1 \%$ PAR level) is consistently shallower than the mixed layer and any nitrate produced from nitrification, a process which is supposedly inhibited by light (Olson, 1981b; Guerero and Jones, 1996), at the bottom of the euphotic layer therefore becomes retained in the surface mixed layer. This aspect is discussed in more detail in a paper by Fripiat et al. (2015). The calculated nitrification rate for the Kerguelen Plateau significantly exceeds some earlier estimates and which led to the conclusion that nitrification is a rather minor process equivalent to $<10 \%$ of phytoplankton nitrate uptake in Southern Ocean waters (Olson, 1981a; Trull et al., 2008; DiFiore et al., 2009). In contrast, high nitrification rates reaching levels similar to the phytoplankton nitrate demand appear to be common for oligotrophic systems (see e.g., Yool et al.., 2007; Wankel et al., 2007; Mulholland and Lomas, 2008 and references therein). Nevertheless, conditions for significant nitrification activity appear to be met in the studied Kerguelen area. For one thing, ammonium concentrations are relatively high, reaching up to $0.5,0.7$ and $0.8 \mu \mathrm{M}$ within the first $100 \mathrm{~m}$ for the PF, Meander and Plateau sites, respectively (Fig. 3), thus providing the substrate for any bacterial and archaeal ammonium oxidizing activity. Furthermore, nitrite concentrations reach up to $0.33 \mu \mathrm{M}$ in the upper $100 \mathrm{~m}$ of water column (Table 1), again indicating nitrification activity is ongoing there. Archaea do abound in the Southern Ocean (Church et al., 2003) and may exhibit a specific affinity for ammonia similar to the one for diatoms, as reported for the cultivated marine ammonia oxidizing archeon (Nitrosopumilus maritimus) (MartensHabbena et al., 2009; Stahl and de la Torre, 2012).

\section{Conclusions}

The present data set adds to the existing data set on dual nitrate isotopic composition for the seasonally ice covered Polar Antarctic Zone (DiFiore et al., 2009) and a meridional section in the Pacific sector (Rafter et al., 2013). It also adds information on the seasonal evolution of nitrate isotopic composition in the iron-fertilized Kerguelen area, by complementing an earlier study that was conducted during summer in the same area (Trull et al., 2008). Published work related to the late summer KEOPS 1 study in the same area as investigated in the present study, highlighted the large difference between the seasonal drawdown of silicic acid and nitrate, with the latter being moderate despite similar $\mathrm{Si}, \mathrm{N}$ uptake rates (Mosseri et al., 2008). Those results pointed toward the occurrence of significant remineralization and nitrate production. The present work confirms the significance of nitrification in the area, with nitrification equivalent to up to $47 \%$ of the nitrate uptake over the Kerguelen Plateau area. This finding of large nitrification rates in nitrate-replete environments was unexpected a priori, in view of the earlier studies outside the Kerguelen area which concluded that there were minor nitrification effects in Southern Ocean surface waters (Olson, 1981a; DiFiore et al., 2009). A direct result of this condition is that estimates of New or Exportable Production which are based on the assumption that all surface water nitrate results from nitrification in the deep ocean and vertical supply to the surface waters, are too high. Correcting New Production for the effect of nitrification would bring closer the estimates of exportable production and Export production during KEOPS 2 , as measured with the ${ }^{234} \mathrm{Th}$ methodology (see papers by Cavagna et al., 2014; Planchon et al., 2014, both in this issue). 
Appendix A

Table A1. Complete data set. Salinity, Tpot, density, $\delta^{15} \mathrm{~N}_{\mathrm{NO} 3}$, $\delta^{18} \mathrm{~N}_{\mathrm{NO} 3}$, concentrations of $\mathrm{NO}_{3}^{-}, \mathrm{NO}_{2}^{-}, \mathrm{NH}_{4}^{+}$; Nutrient data are from Blain et al. (2015).

\begin{tabular}{|c|c|c|c|c|c|c|c|c|c|c|c|c|c|}
\hline Station name & Long $^{\circ} \mathrm{E}$ & $\mathrm{Lat}^{\circ} \mathrm{S}$ & Seafloor, m & $\mathrm{CTD} \mathrm{N}^{\circ}$ & Depth, m & Salinity & $T_{\text {pot }}{ }^{\circ} \mathrm{C}$ & Density, $\sigma_{\theta}$ & $\delta^{15} \mathrm{~N}_{\mathrm{NO}_{3}}, \% o$ & $\delta^{18} \mathrm{O}_{\mathrm{NO}_{3}}, \%$ & {$\left[\mathrm{NO}_{3}^{-}\right], \mu \mathrm{M}$} & {$\left[\mathrm{NO}_{2}^{-}\right], \mu \mathrm{M}$} & {$\left[\mathrm{NH}_{4}^{+}\right], \mu \mathrm{M}$} \\
\hline \multirow[t]{11}{*}{ A3-1 } & \multirow[t]{11}{*}{72.08} & \multirow[t]{11}{*}{-50.63} & \multirow[t]{11}{*}{530} & \multirow[t]{11}{*}{4} & 469 & 34.359 & 2.184 & 27.443 & 5.28 & 3.08 & 35.4 & 0.05 & 0.05 \\
\hline & & & & & 352 & 34.254 & 2.106 & 27.366 & 5.37 & 2.99 & 34.9 & 0.04 & 0.01 \\
\hline & & & & & 278 & 34.137 & 1.821 & 27.294 & 5.61 & 3.71 & 33.7 & 0.03 & 0.03 \\
\hline & & & & & 252 & 34.099 & 1.744 & 27.270 & 5.45 & 2.92 & 33.4 & 0.04 & 0.01 \\
\hline & & & & & 227 & 34.062 & 1.769 & 27.238 & 5.65 & 3.37 & 32.9 & 0.04 & - \\
\hline & & & & & 202 & 34.011 & 1.693 & 27.203 & 5.63 & 3.20 & 32.1 & 0.05 & 0.04 \\
\hline & & & & & 173 & 33.934 & 1.670 & 27.142 & 5.79 & - & 30.7 & 0.2 & 0.06 \\
\hline & & & & & 151 & 33.915 & 1.740 & 27.122 & 5.74 & 3.31 & 29.9 & 0.26 & 0.16 \\
\hline & & & & & 101 & 33.904 & 1.727 & 27.114 & 5.85 & 3.55 & 29.7 & 0.26 & 0.12 \\
\hline & & & & & 41 & 33.897 & 1.698 & 27.111 & 6.89 & 3.43 & 29.2 & 0.27 & 0.08 \\
\hline & & & & & 12 & 33.896 & 1.695 & 27.110 & 5.80 & 3.22 & 28.8 & 0.27 & 0.11 \\
\hline \multirow[t]{13}{*}{ TNS8 } & \multirow[t]{13}{*}{72.24} & -49.46 & 1030 & 8 & 992 & 34.660 & 2.169 & 27.686 & 5.08 & 3.36 & 34.7 & 0.04 & - \\
\hline & & & & & 903 & 34.642 & 2.201 & 27.669 & 5.00 & 2.64 & 34.7 & 0.03 & - \\
\hline & & & & & 702 & 34.565 & 2.257 & 27.602 & 4.93 & 2.77 & 34.7 & 0.03 & - \\
\hline & & & & & 601 & 34.528 & 2.283 & 27.571 & 5.09 & 2.11 & 36.2 & 0.03 & - \\
\hline & & & & & 501 & 34.466 & 2.268 & 27.523 & 5.17 & 2.19 & 36.7 & 0.03 & - \\
\hline & & & & & 401 & 34.374 & 2.182 & 27.456 & 5.27 & 2.41 & 36.2 & 0.03 & 0 \\
\hline & & & & & 303 & 34.244 & 1.954 & 27.369 & 5.42 & 2.31 & 35.7 & 0.04 & 0 \\
\hline & & & & & 251 & 34.113 & 1.909 & 27.268 & 5.40 & 2.50 & 34.2 & 0.04 & 0 \\
\hline & & & & & 203 & 33.912 & 1.796 & 27.116 & 5.89 & 4.15 & 30.0 & 0.18 & 0.17 \\
\hline & & & & & 149 & 33.877 & 1.903 & 27.079 & 6.10 & 3.81 & 29.5 & 0.26 & 0.26 \\
\hline & & & & & 101 & 33.870 & 2.055 & 27.062 & 6.15 & 3.52 & 28.4 & 0.27 & 0.19 \\
\hline & & & & & 41 & 33.867 & 2.126 & 27.054 & 6.10 & 3.74 & 28.6 & 0.28 & 0.19 \\
\hline & & & & & 12 & 33.867 & 2.126 & 27.054 & 6.07 & 3.41 & 28.1 & 0.28 & 0.20 \\
\hline TNS6 & 72.28 & -48.78 & 1885 & 10 & 1871 & 34.742 & 1.621 & 27.794 & 4.87 & 2.56 & 31.3 & 0.01 & - \\
\hline & & & & & 1514 & 34.740 & 1.835 & 27.776 & 4.92 & 2.32 & 31.7 & 0 & - \\
\hline & & & & & 807 & 34.628 & 2.280 & 27.651 & 5.30 & 2.26 & 34.6 & 0.01 & - \\
\hline & & & & & 605 & 34.522 & 2.290 & 27.565 & 4.87 & 2.38 & 35.1 & 0.01 & - \\
\hline & & & & & 505 & 34.470 & 2.352 & 27.518 & 4.85 & 3.14 & 35.5 & 0.02 & - \\
\hline & & & & & 404 & 34.345 & 2.102 & 27.439 & 5.14 & 1.95 & 35.9 & 0.01 & 0 \\
\hline & & & & & 303 & 34.244 & 2.082 & 27.360 & 5.26 & 2.03 & 34.6 & 0.02 & 0.02 \\
\hline & & & & & 253 & 34.116 & 1.940 & 27.268 & 5.16 & 2.46 & 33.2 & 0.02 & 0.01 \\
\hline & & & & & 202 & 34.035 & 2.059 & 27.194 & 5.49 & 2.99 & 32.4 & 0.03 & 0.01 \\
\hline & & & & & 183 & 33.995 & 2.012 & 27.165 & 5.32 & 2.85 & 31.6 & 0.04 & 0.01 \\
\hline & & & & & 102 & 33.852 & 2.056 & 27.047 & 6.07 & 3.71 & 27.5 & 0.29 & 0.45 \\
\hline & & & & & 41 & 33.845 & 2.296 & 27.023 & 6.01 & 3.72 & 27.5 & 0.28 & 0.38 \\
\hline & & & & & 12 & 33.844 & 2.426 & 27.012 & 6.15 & 3.59 & 27.0 & 0.28 & 0.25 \\
\hline TNS1 & 71.50 & -46.83 & 2280 & 15 & 2263 & 34.743 & 1.330 & 27.816 & 5.18 & 2.88 & 30.2 & 0.03 & 0 \\
\hline & & & & & 1508 & 34.748 & 2.100 & 27.762 & 5.21 & 2.18 & 29.9 & 0.04 & 0 \\
\hline & & & & & 802 & 34.547 & 2.435 & 27.573 & 5.12 & 2.08 & 33.7 & 0.03 & 0 \\
\hline & & & & & 602 & 34.431 & 2.542 & 27.472 & 5.25 & 2.96 & 33.5 & 0.05 & 0 \\
\hline & & & & & 502 & 34.308 & 2.539 & 27.373 & 5.41 & 3.44 & - & - & - \\
\hline & & & & & 402 & 34.209 & 2.492 & 27.298 & 5.49 & 4.55 & 34.1 & 0.03 & 0 \\
\hline & & & & & 302 & 34.061 & 2.446 & 27.184 & 5.75 & 4.01 & 30.8 & 0.03 & 0 \\
\hline & & & & & 251 & 33.990 & 2.579 & 27.116 & 5.75 & 3.93 & 29.1 & 0.07 & 0 \\
\hline & & & & & 201 & 33.891 & 2.819 & 27.015 & 6.23 & 3.94 & 27.4 & 0.04 & 0 \\
\hline & & & & & 151 & 33.780 & 3.020 & 26.910 & 6.23 & 5.16 & 25.9 & 0.11 & 0 \\
\hline & & & & & 102 & 33.718 & 3.784 & 26.788 & 6.27 & 4.70 & 24.1 & 0.31 & 0.19 \\
\hline & & & & & 41 & 33.714 & 3.994 & 26.764 & 6.82 & 5.09 & 23.7 & 0.29 & 0.11 \\
\hline & & & & & 11 & 33.714 & 4.168 & 26.746 & 6.63 & 5.26 & 23.9 & 0.3 & 0.08 \\
\hline $\mathrm{R}-2$ & 66.72 & -50.36 & 2532 & 17 & 904 & 34.616 & 2.329 & 27.637 & 5.16 & 2.52 & 33.9 & 0.03 & 0.03 \\
\hline & & & & & 703 & 34.516 & 2.369 & 27.554 & 5.09 & 2.04 & 35.2 & 0.04 & 0.04 \\
\hline & & & & & 603 & 34.440 & 2.413 & 27.489 & 5.17 & 2.23 & 35.3 & 0.07 & 0.07 \\
\hline & & & & & 503 & 34.343 & 2.306 & 27.421 & 5.04 & 2.51 & 35.1 & 0.04 & 0.04 \\
\hline & & & & & 401 & 34.250 & 2.263 & 27.350 & 5.19 & 2.61 & 34.1 & 0.04 & 0.04 \\
\hline & & & & & 251 & 34.018 & 2.028 & 27.183 & 5.53 & 2.91 & - & - & - \\
\hline & & & & & 201 & 33.900 & 1.860 & 27.101 & 5.37 & 3.14 & 28.8 & 0.05 & 0.05 \\
\hline & & & & & 100 & 33.771 & 2.025 & 26.985 & 6.12 & - & 25.8 & 0.32 & 0.32 \\
\hline & & & & & 79 & 33.770 & 2.104 & 26.978 & 6.12 & 4.03 & 25.9 & 0.32 & 0.32 \\
\hline & & & & & 40 & 33.771 & 2.174 & 26.973 & 6.24 & 3.91 & 25.7 & 0.32 & 0.32 \\
\hline & & & & & 21 & 33.771 & 2.177 & 26.973 & 6.14 & 3.82 & 25.4 & 0.31 & 0.31 \\
\hline $\mathrm{R}-2$ & 66.69 & -50.39 & 2450 & 20 & 2453 & 34.734 & 1.107 & 27.824 & 4.81 & 1.96 & 32.8 & 0.04 & - \\
\hline & & & & & 1817 & 34.759 & 1.686 & 27.803 & 5.07 & 2.12 & 31.5 & 0.04 & - \\
\hline & & & & & 1508 & 34.750 & 1.953 & 27.775 & 4.96 & 1.75 & 31.5 & 0.05 & - \\
\hline & & & & & 1003 & 34.663 & 2.288 & 27.678 & 5.15 & 2.12 & 33.6 & 0.04 & - \\
\hline & & & & & 806 & 34.584 & 2.346 & 27.610 & 5.12 & 2.37 & 35.6 & 0.03 & - \\
\hline & & & & & 605 & 34.455 & 2.410 & 27.502 & 5.13 & 2.39 & 36.9 & 0.04 & - \\
\hline & & & & & 503 & 34.367 & 2.428 & 27.429 & 5.13 & 2.02 & 36.8 & 0.03 & - \\
\hline & & & & & 353 & 34.180 & 2.251 & 27.295 & 5.43 & 2.32 & 34.5 & 0.04 & - \\
\hline
\end{tabular}


Table A1. Continued.

\begin{tabular}{|c|c|c|c|c|c|c|c|c|c|c|c|c|c|}
\hline Station name & Long $^{\circ} \mathrm{E}$ & Lat $^{\circ} \mathrm{S}$ & Seafloor, $\mathrm{m}$ & $\mathrm{CTD} \mathrm{N}^{\circ}$ & Depth, m & Salinity & $T_{\text {pot }}{ }^{\circ} \mathrm{C}$ & Density, $\sigma_{\theta}$ & $\delta^{15} \mathrm{~N}_{\mathrm{NO}_{3}}, \%$ & $\delta^{18} \mathrm{O}_{\mathrm{NO}_{3}}, \% o$ & {$\left[\mathrm{NO}_{3}^{-}\right], \mu \mathrm{M}$} & {$\left[\mathrm{NO}_{2}^{-}\right], \mu \mathrm{M}$} & {$\left[\mathrm{NH}_{4}^{+}\right], \mu \mathrm{M}$} \\
\hline \multirow[t]{13}{*}{ E1 } & \multirow[t]{13}{*}{72.19} & \multirow[t]{13}{*}{-48.46} & \multirow[t]{13}{*}{2056} & \multirow[t]{13}{*}{27} & 906 & 34.644 & 2.202 & 27.670 & 5.17 & 2.49 & 33.2 & 0.02 & - \\
\hline & & & & & 702 & 34.569 & 2.231 & 27.608 & 5.17 & 2.59 & 33.8 & 0.02 & - \\
\hline & & & & & 600 & 34.520 & 2.235 & 27.568 & 5.15 & 2.30 & 34.0 & 0.03 & - \\
\hline & & & & & 501 & 34.465 & 2.251 & 27.523 & 5.23 & 2.51 & 35.1 & 0.03 & - \\
\hline & & & & & 400 & 34.385 & 2.188 & 27.464 & 5.32 & 2.68 & 34.5 & 0.03 & - \\
\hline & & & & & 301 & 34.236 & 1.962 & 27.362 & 5.25 & 2.73 & - & - & - \\
\hline & & & & & 251 & 34.148 & 1.870 & 27.299 & 5.24 & 2.66 & - & - & - \\
\hline & & & & & 180 & 33.964 & 1.813 & 27.156 & 5.71 & 3.46 & 29.3 & 0.08 & 0.01 \\
\hline & & & & & 150 & 33.881 & 2.012 & 27.074 & 5.97 & 3.71 & 27.3 & 0.26 & 0.30 \\
\hline & & & & & 124 & 33.874 & 2.139 & 27.059 & 6.32 & 4.41 & 26.4 & 0.27 & 0.41 \\
\hline & & & & & 100 & 33.865 & 2.212 & 27.046 & 6.20 & 3.95 & 25.4 & 0.27 & 0.39 \\
\hline & & & & & 81 & 33.855 & 2.375 & 27.025 & 6.04 & 3.85 & 25.9 & 0.27 & 0.32 \\
\hline & & & & & 40 & 33.852 & 2.500 & 27.012 & 6.25 & 3.87 & 25.5 & 0.26 & 0.19 \\
\hline \multirow[t]{9}{*}{ E1 } & \multirow[t]{9}{*}{72.18} & \multirow[t]{9}{*}{-48.50} & 2058 & 30 & 2025 & 34.740 & 1.416 & 27.808 & 4.94 & 1.98 & 33.0 & 0.03 & - \\
\hline & & & & & 1486 & 34.737 & 1.860 & 27.772 & 4.93 & 2.41 & 32.2 & 0.03 & - \\
\hline & & & & & 1003 & 34.675 & 2.179 & 27.697 & 5.00 & 2.90 & 34.2 & 0.03 & - \\
\hline & & & & & 802 & 34.623 & 2.263 & 27.649 & 5.15 & 2.85 & 35.6 & 0.03 & - \\
\hline & & & & & 631 & 34.554 & 2.270 & 27.592 & 5.22 & 2.69 & 36.9 & 0.03 & - \\
\hline & & & & & 501 & 34.477 & 2.321 & 27.527 & 5.18 & 1.99 & 36.7 & 0.04 & - \\
\hline & & & & & 451 & 34.434 & 2.306 & 27.493 & 5.23 & 2.35 & 37.0 & 0.04 & - \\
\hline & & & & & 350 & 34.326 & 2.171 & 27.418 & 5.06 & 2.25 & 36.2 & 0.04 & - \\
\hline & & & & & 300 & 34.249 & 1.972 & 27.372 & 5.06 & 2.46 & 35.5 & 0.04 & - \\
\hline TEW1 & 69.83 & -49.15 & 92 & 35 & 71 & 33.656 & 2.519 & 26.854 & 6.08 & 3.95 & 27.1 & 0.34 & 1.15 \\
\hline & & & & & 60 & 33.652 & 2.575 & 26.846 & 5.93 & 3.59 & 26.9 & 0.33 & 0.99 \\
\hline & & & & & 51 & 33.639 & 2.722 & 26.823 & 6.20 & 4.03 & 26.2 & 0.31 & 1.02 \\
\hline & & & & & 41 & 33.627 & 2.830 & 26.804 & 6.19 & 3.86 & 25.5 & 0.31 & 0.78 \\
\hline & & & & & 31 & 33.621 & 2.922 & 26.791 & 6.34 & 4.00 & 25.6 & 0.31 & 0.67 \\
\hline & & & & & 20 & 33.620 & 2.981 & 26.786 & 6.40 & 4.18 & 24.4 & 0.31 & 0.52 \\
\hline & & & & & 10 & 33.611 & 3.369 & 26.743 & 6.70 & 4.40 & 23.6 & 0.31 & 0.19 \\
\hline TEW3 & 71.02 & -48.80 & 570 & 38 & 541 & 34.369 & 2.184 & 27.452 & 4.85 & 2.43 & 34.0 & 0.04 & 0.01 \\
\hline & & & & & 401 & 34.253 & 2.148 & 27.361 & 5.04 & 2.44 & 33.9 & 0.07 & 0 \\
\hline & & & & & 276 & 34.107 & 2.073 & 27.251 & 5.07 & 2.72 & 31.6 & 0.07 & 0 \\
\hline & & & & & 252 & 34.095 & 2.064 & 27.242 & 5.34 & 2.53 & 31.6 & 0.07 & 0 \\
\hline & & & & & 182 & 33.953 & 1.974 & 27.134 & 5.46 & 3.16 & 28.4 & 0.19 & 0.08 \\
\hline & & & & & 111 & 33.892 & 1.980 & 27.085 & 5.57 & 3.39 & 27.8 & 0.27 & 0.18 \\
\hline & & & & & 91 & 33.879 & 2.025 & 27.072 & 5.73 & 3.97 & 27.9 & 0.24 & 0.15 \\
\hline & & & & & 76 & 33.876 & 2.075 & 27.065 & 5.92 & 3.79 & 27.1 & 0.24 & 0.13 \\
\hline & & & & & 61 & 33.872 & 2.131 & 27.058 & 6.18 & 3.66 & 27.2 & 0.24 & 0.09 \\
\hline & & & & & 40 & 33.865 & 2.137 & 27.052 & 6.04 & 3.78 & 27.2 & 0.25 & 0.12 \\
\hline & & & & & 16 & 33.868 & 2.315 & 27.040 & 5.91 & 3.73 & 26.5 & 0.25 & 0.09 \\
\hline TEW4 & 71.62 & -48.63 & 1579 & 42 & 1567 & 34.730 & 1.895 & 27.764 & 5.16 & 2.08 & 31.7 & 0.03 & - \\
\hline & & & & & 1004 & 34.662 & 2.164 & 27.688 & 4.88 & 2.02 & 33.6 & 0.03 & - \\
\hline & & & & & 802 & 34.598 & 2.242 & 27.630 & 4.91 & 2.34 & 34.5 & 0.03 & - \\
\hline & & & & & 602 & 34.514 & 2.275 & 27.560 & 4.94 & 1.81 & 35.2 & 0.03 & - \\
\hline & & & & & 502 & 34.438 & 2.238 & 27.502 & 4.97 & 2.01 & 35.5 & 0.03 & - \\
\hline & & & & & 301 & 34.193 & 1.887 & 27.334 & 5.08 & 2.05 & - & - & - \\
\hline & & & & & 300 & 34.189 & 1.882 & 27.331 & 5.13 & 2.26 & 33.9 & 0.03 & 0 \\
\hline & & & & & 251 & 34.086 & 1.773 & 27.256 & 4.93 & 2.00 & 33.1 & 0.03 & 0 \\
\hline & & & & & 201 & 33.928 & 1.733 & 27.133 & 5.52 & 2.82 & 29.8 & 0.19 & 0.16 \\
\hline & & & & & 151 & 33.892 & 1.903 & 27.091 & 5.80 & 3.62 & 28.1 & 0.25 & 0.36 \\
\hline & & & & & 101 & 33.865 & 2.370 & 27.033 & 5.95 & 3.37 & 26.1 & 0.26 & 0.37 \\
\hline & & & & & 41 & 33.854 & 2.567 & 27.008 & 6.17 & 4.04 & 25.5 & 0.25 & 0.13 \\
\hline & & & & & 11 & 33.855 & 2.618 & 27.004 & 6.20 & 4.30 & 25.3 & 0.25 & 0.11 \\
\hline TEW5 & 72.80 & -48.47 & 2275 & 44 & 2271 & 34.730 & 1.130 & 27.820 & 4.73 & 1.75 & 31.6 & 0.04 & - \\
\hline & & & & & 1003 & 34.685 & 2.181 & 27.705 & 5.04 & 1.63 & 33.9 & 0.03 & - \\
\hline & & & & & 801 & 34.621 & 2.252 & 27.647 & 5.06 & 2.25 & 34.7 & 0.04 & - \\
\hline & & & & & 601 & 34.522 & 2.277 & 27.566 & 4.86 & 1.65 & 36.4 & 0.04 & - \\
\hline & & & & & 501 & 34.446 & 2.240 & 27.509 & 5.11 & 2.50 & 35.7 & 0.04 & - \\
\hline & & & & & 401 & 34.351 & 2.140 & 27.440 & 5.15 & 2.23 & 35.1 & 0.04 & 0 \\
\hline & & & & & 301 & 34.210 & 1.997 & 27.339 & 5.23 & 2.12 & 34.6 & 0.05 & 0 \\
\hline & & & & & 251 & 34.106 & 1.890 & 27.264 & 5.27 & 3.11 & 32.6 & 0.04 & 0 \\
\hline & & & & & 201 & 33.959 & 1.833 & 27.150 & 5.50 & 2.81 & 30.8 & 0.08 & 0.01 \\
\hline & & & & & 151 & 33.880 & 1.840 & 27.087 & 5.70 & 3.42 & 28.9 & 0.26 & 0.30 \\
\hline & & & & & 101 & 33.858 & 2.016 & 27.055 & 5.97 & 3.73 & 28.5 & 0.3 & 0.48 \\
\hline & & & & & 60 & 33.851 & 2.376 & 27.021 & 6.24 & 3.57 & 26.3 & 0.29 & 0.43 \\
\hline & & & & & 41 & 33.849 & 2.508 & 27.008 & 6.10 & 3.57 & 26.6 & 0.27 & 0.27 \\
\hline & & & & & 10 & 33.848 & 2.704 & 26.992 & 6.43 & 4.00 & 26.6 & 0.26 & 0.19 \\
\hline
\end{tabular}


Table A1. Continued.

\begin{tabular}{|c|c|c|c|c|c|c|c|c|c|c|c|c|c|}
\hline Station name & Long $^{\circ} \mathrm{E}$ & $\mathrm{Lat}^{\circ} \mathrm{S}$ & Seafloor, m & $\mathrm{CTD} \mathrm{N}^{\circ}$ & Depth, m & Salinity & $T_{\text {pot }}{ }^{\circ} \mathrm{C}$ & Density, $\sigma_{\theta}$ & $\delta^{15} \mathrm{~N}_{\mathrm{NO}_{3}}, \%$ & $\delta^{18} \mathrm{O}_{\mathrm{NO}_{3}}, \%$ & {$\left[\mathrm{NO}_{3}^{-}\right], \mu \mathrm{M}$} & {$\left[\mathrm{NO}_{2}^{-}\right], \mu \mathrm{M}$} & {$\left[\mathrm{NH}_{4}^{+}\right], \mu \mathrm{M}$} \\
\hline \multirow[t]{14}{*}{ TEW6 } & \multirow{14}{*}{73.40} & \multirow{14}{*}{-48.47} & \multirow[t]{14}{*}{2410} & \multirow[t]{14}{*}{45} & 2403 & 34.710 & 0.709 & 27.831 & 4.73 & 2.08 & 33.3 & 0.03 & - \\
\hline & & & & & 1004 & 34.675 & 2.204 & 27.695 & 5.16 & 2.22 & 33.7 & 0.03 & - \\
\hline & & & & & 802 & 34.621 & 2.257 & 27.647 & 4.75 & 1.89 & 34.6 & 0.03 & - \\
\hline & & & & & 602 & 34.544 & 2.283 & 27.584 & 4.95 & 2.53 & 35.1 & 0.03 & - \\
\hline & & & & & 502 & 34.471 & 2.232 & 27.529 & 5.02 & 1.84 & 35.5 & 0.03 & - \\
\hline & & & & & 401 & 34.392 & 2.170 & 27.471 & 5.07 & 2.37 & 35.5 & 0.03 & 0 \\
\hline & & & & & 302 & 34.256 & 2.056 & 27.371 & 5.12 & 2.76 & 35.1 & 0.03 & 0 \\
\hline & & & & & 251 & 34.164 & 2.080 & 27.296 & 5.22 & 2.07 & 34.5 & 0.03 & 0 \\
\hline & & & & & 202 & 34.057 & 1.952 & 27.220 & 5.22 & 2.57 & 32.8 & 0.04 & 0.01 \\
\hline & & & & & 151 & 33.919 & 1.783 & 27.122 & 5.82 & 3.31 & 30.5 & 0.08 & 0.01 \\
\hline & & & & & 101 & 33.855 & 2.198 & 27.039 & 5.89 & 3.48 & 28.0 & 0.29 & 0.46 \\
\hline & & & & & 61 & 33.844 & 2.499 & 27.006 & 6.08 & 3.50 & 27.0 & 0.27 & 0.49 \\
\hline & & & & & 41 & 33.842 & 2.569 & 26.998 & 6.10 & 3.61 & 26.5 & 0.25 & 0.29 \\
\hline & & & & & 12 & 33.844 & 2.959 & 26.966 & 6.28 & 5.28 & 25.6 & 0.25 & 0.22 \\
\hline \multirow[t]{13}{*}{ TEW7 } & \multirow[t]{13}{*}{74.00} & \multirow[t]{13}{*}{-48.47} & \multirow[t]{13}{*}{2510} & \multirow[t]{13}{*}{46} & 2503 & 34.700 & 0.497 & 27.836 & 4.59 & 1.67 & 33.2 & 0.03 & - \\
\hline & & & & & 1506 & 34.734 & 1.975 & 27.760 & 4.82 & 1.89 & 31.7 & 0.02 & - \\
\hline & & & & & 802 & 34.580 & 2.320 & 27.609 & 4.86 & 1.41 & 34.4 & 0.02 & - \\
\hline & & & & & 601 & 34.483 & 2.386 & 27.526 & 5.15 & 1.72 & 35.1 & 0.02 & - \\
\hline & & & & & 501 & 34.380 & 2.331 & 27.448 & 5.01 & 1.97 & 36.0 & 0.02 & - \\
\hline & & & & & 401 & 34.253 & 2.541 & 27.329 & 5.26 & 2.10 & 35.3 & 0.02 & 0 \\
\hline & & & & & 301 & 34.194 & 3.018 & 27.240 & 5.57 & 2.46 & 32.7 & 0.02 & 0 \\
\hline & & & & & 251 & 34.157 & 3.264 & 27.188 & 5.48 & 2.59 & 32.7 & 0.03 & 0 \\
\hline & & & & & 201 & 34.098 & 3.440 & 27.124 & 5.63 & 2.80 & 30.7 & 0.03 & 0 \\
\hline & & & & & 150 & 34.009 & 3.308 & 27.066 & 5.65 & 3.18 & 30.0 & 0.07 & 0.01 \\
\hline & & & & & 101 & 33.849 & 2.709 & 26.992 & 5.77 & 3.03 & 27.7 & 0.21 & 0.37 \\
\hline & & & & & 61 & 33.794 & 3.446 & 26.881 & 6.34 & 4.02 & 24.8 & 0.24 & 0.47 \\
\hline & & & & & 41 & 33.788 & 3.825 & 26.839 & 7.04 & 4.40 & 21.6 & 0.24 & 0.38 \\
\hline \multirow[t]{14}{*}{ TEW8 } & \multirow[t]{14}{*}{75.00} & \multirow[t]{14}{*}{-48.47} & \multirow[t]{14}{*}{2786} & \multirow[t]{14}{*}{47} & 2788 & 34.695 & 0.399 & 27.838 & 4.27 & 1.58 & 33.0 & 0.02 & - \\
\hline & & & & & 1003 & 34.665 & 2.348 & 27.675 & 4.48 & 1.31 & 33.3 & 0.02 & - \\
\hline & & & & & 803 & 34.593 & 2.395 & 27.613 & 4.63 & 1.50 & 34.5 & 0.02 & - \\
\hline & & & & & 604 & 34.449 & 2.394 & 27.498 & 4.54 & 1.47 & 35.1 & 0.02 & - \\
\hline & & & & & 503 & 34.362 & 2.304 & 27.436 & 4.56 & 1.87 & 35.5 & 0.02 & - \\
\hline & & & & & 403 & 34.273 & 2.280 & 27.367 & 4.74 & 1.72 & 35.5 & 0.03 & 0 \\
\hline & & & & & 301 & 34.077 & 1.970 & 27.234 & 5.16 & 2.76 & 32.7 & 0.02 & 0 \\
\hline & & & & & 252 & 34.024 & 2.147 & 27.178 & 4.77 & 1.97 & 32.0 & 0.03 & 0 \\
\hline & & & & & 201 & 33.946 & 2.048 & 27.123 & 5.24 & 3.02 & 30.4 & 0.05 & 0 \\
\hline & & & & & 151 & 33.881 & 2.107 & 27.067 & 5.65 & 2.90 & 29.2 & 0.26 & 0.11 \\
\hline & & & & & 101 & 33.844 & 2.280 & 27.024 & 5.57 & 3.06 & 27.7 & 0.25 & 0.43 \\
\hline & & & & & 40 & 33.785 & 3.596 & 26.860 & 5.49 & 3.18 & - & - & - \\
\hline & & & & & 40 & 33.786 & 3.621 & 26.858 & 6.28 & 4.17 & 23.4 & 0.23 & 0.45 \\
\hline & & & & & 11 & 33.766 & 4.197 & 26.785 & 7.19 & 5.29 & 18.9 & 0.25 & 0.12 \\
\hline E3 & 71.97 & -48.70 & 1915 & 50 & 904 & 34.645 & 2.233 & 27.668 & 4.78 & 1.46 & 34.4 & 0.03 & - \\
\hline & & & & & 701 & 34.570 & 2.300 & 27.603 & 4.84 & 1.68 & 35.5 & 0.03 & - \\
\hline & & & & & 603 & 34.515 & 2.272 & 27.561 & 4.74 & 1.46 & 36.2 & 0.03 & - \\
\hline & & & & & 500 & 34.462 & 2.255 & 27.520 & 5.00 & 1.79 & - & - & - \\
\hline & & & & & 402 & 34.346 & 2.146 & 27.436 & 4.91 & 1.43 & 36.1 & 0.03 & 0 \\
\hline & & & & & 201 & 33.932 & 1.765 & 27.134 & 5.38 & 2.89 & 31.1 & 0.1 & 0.01 \\
\hline & & & & & 153 & 33.883 & 1.940 & 27.081 & 5.91 & 3.04 & 27.9 & 0.29 & 0.39 \\
\hline & & & & & 124 & 33.886 & 2.107 & 27.071 & 5.92 & 2.89 & 27.7 & 0.27 & 0.53 \\
\hline & & & & & 101 & 33.861 & 2.082 & 27.053 & 5.80 & 3.81 & 28.2 & 0.3 & 0.45 \\
\hline & & & & & 71 & 33.853 & 2.261 & 27.032 & 6.05 & 3.65 & 27.5 & 0.3 & 0.51 \\
\hline & & & & & 41 & 33.846 & 2.687 & 26.991 & 6.08 & 3.30 & 26.5 & 0.27 & 0.30 \\
\hline & & & & & 11 & 33.845 & 2.908 & 26.971 & 6.24 & 3.43 & 25.4 & 0.27 & 0.24 \\
\hline
\end{tabular}


Table A1. Continued.

\begin{tabular}{|c|c|c|c|c|c|c|c|c|c|c|c|c|c|}
\hline Station name & Long $^{\circ} \mathrm{E}$ & $\mathrm{Lat}^{\circ} \mathrm{S}$ & Seafloor, m & $\mathrm{CTD} \mathrm{N}^{\circ}$ & Depth, m & Salinity & $T_{\text {pot }}{ }^{\circ} \mathrm{C}$ & Density, $\sigma_{\theta}$ & $\delta^{15} \mathrm{~N}_{\mathrm{NO}_{3}}, \%$ & $\delta^{18} \mathrm{O}_{\mathrm{NO}_{3}}, \%$ & {$\left[\mathrm{NO}_{3}^{-}\right], \mu \mathrm{M}$} & {$\left[\mathrm{NO}_{2}^{-}\right], \mu \mathrm{M}$} & {$\left[\mathrm{NH}_{4}^{+}\right], \mu \mathrm{M}$} \\
\hline \multirow[t]{12}{*}{ E3 } & \multirow[t]{12}{*}{71.97} & \multirow[t]{12}{*}{-48.70} & \multirow[t]{12}{*}{1910} & \multirow[t]{12}{*}{55} & 1893 & 34.743 & 1.641 & 27.794 & 4.78 & 1.65 & 30.6 & 0.02 & - \\
\hline & & & & & 1204 & 34.703 & 2.107 & 27.725 & 4.72 & 1.23 & 31.6 & 0.02 & - \\
\hline & & & & & 1004 & 34.663 & 2.174 & 27.688 & 4.63 & 0.96 & 33.1 & 0.02 & - \\
\hline & & & & & 903 & 34.639 & 2.202 & 27.666 & 4.52 & 0.97 & 32.9 & 0.02 & - \\
\hline & & & & & 803 & 34.613 & 2.220 & 27.644 & 4.82 & 1.01 & 33.9 & 0.02 & - \\
\hline & & & & & 601 & 34.536 & 2.287 & 27.577 & 4.81 & 1.50 & 34.2 & 0.02 & - \\
\hline & & & & & 501 & 34.458 & 2.264 & 27.516 & 4.83 & 1.22 & 34.1 & 0.02 & - \\
\hline & & & & & 451 & 34.398 & 2.208 & 27.472 & 4.84 & 1.55 & 34.1 & 0.02 & - \\
\hline & & & & & 401 & 34.340 & 2.132 & 27.433 & 4.94 & 1.69 & 33.3 & 0.02 & - \\
\hline & & & & & 225 & 34.068 & 1.890 & 27.233 & 5.14 & 2.65 & 32.0 & 0.03 & - \\
\hline & & & & & 106 & 33.851 & 2.189 & 27.037 & 5.88 & 3.09 & 26.6 & 0.3 & - \\
\hline & & & & & 51 & 33.846 & 2.556 & 27.002 & 6.20 & 3.38 & 25.1 & 0.26 & - \\
\hline \multirow[t]{11}{*}{ F-L } & \multirow[t]{11}{*}{74.66} & -48.53 & 2695 & 63 & 903 & 34.607 & 2.356 & 27.628 & 4.96 & 1.39 & 34.3 & 0.02 & - \\
\hline & & & & & 502 & 34.388 & 2.674 & 27.426 & 5.13 & 1.97 & 35.3 & 0.02 & - \\
\hline & & & & & 401 & 34.355 & 3.050 & 27.366 & 5.26 & 2.02 & 35.2 & 0.03 & - \\
\hline & & & & & 302 & 34.206 & 2.879 & 27.262 & 5.33 & 1.80 & 33.8 & 0.03 & 0 \\
\hline & & & & & 151 & 33.905 & 2.250 & 27.075 & 5.46 & 3.54 & 29.9 & 0.04 & 0 \\
\hline & & & & & 126 & 33.878 & 2.354 & 27.045 & 5.58 & 3.34 & 29.4 & 0.14 & 0 \\
\hline & & & & & 101 & 33.836 & 2.631 & 26.988 & 5.82 & 2.97 & 28.4 & 0.31 & 0.19 \\
\hline & & & & & 82 & 33.794 & 3.176 & 26.907 & 6.00 & 3.46 & 26.8 & 0.27 & 0.43 \\
\hline & & & & & 61 & 33.749 & 3.917 & 26.799 & 6.81 & 4.12 & 22.9 & 0.27 & 0.45 \\
\hline & & & & & 35 & 33.747 & 4.030 & 26.787 & 7.10 & 4.69 & 21.5 & 0.27 & 0.30 \\
\hline & & & & & 11 & 33.744 & 4.318 & 26.754 & 7.74 & 5.44 & 18.9 & 0.27 & 0.08 \\
\hline F-L & 74.81 & -48.62 & 2739 & 68 & 2719 & 34.691 & 0.322 & 27.839 & 4.73 & 2.09 & 31.5 & 0.03 & - \\
\hline & & & & & 1758 & 34.746 & 1.758 & 27.787 & 4.87 & 1.28 & 32.4 & 0.03 & - \\
\hline & & & & & 1205 & 34.706 & 2.266 & 27.715 & 4.81 & 1.56 & 34.0 & 0.03 & - \\
\hline & & & & & 1005 & 34.657 & 2.388 & 27.665 & 4.97 & 1.57 & 34.0 & 0.03 & - \\
\hline & & & & & 902 & 34.620 & 2.443 & 27.631 & 4.91 & 1.42 & 36.2 & 0.03 & - \\
\hline & & & & & 602 & 34.471 & 2.731 & 27.487 & 5.13 & 1.12 & 36.3 & 0.04 & - \\
\hline & & & & & 502 & 34.391 & 2.677 & 27.427 & 5.16 & 1.33 & 36.4 & 0.03 & - \\
\hline & & & & & 452 & 34.356 & 2.643 & 27.403 & 5.08 & 1.84 & 35.9 & 0.03 & - \\
\hline & & & & & 402 & 34.316 & 2.769 & 27.360 & 5.09 & 1.93 & 35.2 & 0.03 & - \\
\hline & & & & & 302 & 34.257 & 3.185 & 27.275 & 5.28 & 1.91 & 34.0 & 0.04 & - \\
\hline & & & & & 30 & 33.749 & 4.194 & 26.771 & 7.70 & 5.58 & 18.6 & 0.28 & - \\
\hline E4W & 71.43 & -48.77 & 1400 & 81 & 903 & 34.601 & 2.223 & 27.634 & 4.94 & 1.86 & 35.1 & 0.02 & - \\
\hline & & & & & 703 & 34.539 & 2.219 & 27.585 & 4.88 & 1.50 & 35.1 & 0.02 & - \\
\hline & & & & & 603 & 34.507 & 2.250 & 27.557 & 4.84 & 1.33 & 35.8 & 0.02 & - \\
\hline & & & & & 503 & 34.457 & 2.196 & 27.521 & 4.79 & 1.85 & 35.5 & 0.02 & - \\
\hline & & & & & 402 & 34.368 & 2.130 & 27.455 & 4.99 & 1.62 & 35.6 & 0.02 & 0.01 \\
\hline & & & & & 202 & 34.069 & 1.783 & 27.243 & 5.23 & 1.94 & 32.3 & 0.04 & 0.01 \\
\hline & & & & & 151 & 33.911 & 1.653 & 27.125 & 5.69 & 2.90 & 29.0 & 0.28 & 0.28 \\
\hline & & & & & 126 & 33.914 & 1.876 & 27.111 & 5.70 & 2.95 & 28.9 & 0.32 & 0.24 \\
\hline & & & & & 91 & 33.916 & 1.948 & 27.107 & 5.61 & 2.64 & 28.4 & 0.32 & 0.21 \\
\hline & & & & & 70 & 33.898 & 2.309 & 27.064 & 6.28 & 3.43 & 26.3 & 0.29 & 0.24 \\
\hline & & & & & 41 & 33.899 & 2.627 & 27.039 & 6.40 & 3.96 & 24.6 & 0.28 & 0.05 \\
\hline & & & & & 10 & 33.899 & 2.628 & 27.038 & 6.38 & 3.84 & 24.5 & 0.28 & 0.05 \\
\hline E4W1 & 71.43 & -48.77 & 1384 & 87 & 1372 & 34.727 & 1.922 & 27.759 & 4.84 & 2.26 & 32.0 & 0.03 & - \\
\hline & & & & & 1204 & 34.698 & 2.069 & 27.724 & 4.87 & 1.58 & 33.1 & 0.02 & - \\
\hline & & & & & 1003 & 34.638 & 2.195 & 27.666 & 5.07 & 1.87 & 34.0 & 0.02 & - \\
\hline & & & & & 903 & 34.614 & 2.213 & 27.645 & 5.02 & 2.31 & 34.4 & 0.02 & - \\
\hline & & & & & 804 & 34.581 & 2.226 & 27.618 & 4.93 & 1.61 & 34.8 & 0.02 & - \\
\hline & & & & & 602 & 34.516 & 2.218 & 27.567 & 4.92 & 2.13 & 35.0 & 0.02 & - \\
\hline & & & & & 449 & 34.444 & 2.194 & 27.510 & 4.89 & 1.63 & 35.1 & 0.02 & - \\
\hline & & & & & 351 & 34.349 & 2.102 & 27.442 & 5.05 & 1.60 & 35.3 & 0.03 & - \\
\hline & & & & & 302 & 34.262 & 2.071 & 27.375 & 5.10 & 2.22 & 34.0 & 0.03 & - \\
\hline & & & & & 160 & 33.930 & 1.721 & 27.135 & 5.76 & 2.96 & 29.6 & 0.31 & - \\
\hline & & & & & 50 & 33.897 & 2.561 & 27.043 & 6.48 & 3.93 & 25.3 & 0.28 & - \\
\hline & & & & & 30 & 33.897 & 2.599 & 27.039 & 6.49 & 3.61 & 24.7 & 0.28 & - \\
\hline $\mathrm{E} 4 \mathrm{E}$ & 72.56 & -48.72 & 2210 & 94 & 903 & 34.661 & 2.304 & 27.676 & 5.00 & 1.30 & 33.9 & 0.02 & - \\
\hline & & & & & 702 & 34.581 & 2.275 & 27.614 & 4.93 & 1.25 & 35.1 & 0.02 & - \\
\hline & & & & & 602 & 34.526 & 2.296 & 27.568 & 4.92 & 1.61 & 35.1 & 0.03 & - \\
\hline & & & & & 501 & 34.459 & 2.276 & 27.516 & 4.95 & 1.51 & 36.8 & 0.03 & 0.01 \\
\hline & & & & & 401 & 34.352 & 2.236 & 27.434 & 5.08 & 2.15 & 35.1 & 0.03 & 0 \\
\hline & & & & & 181 & 33.937 & 1.808 & 27.134 & 5.50 & 2.71 & 29.9 & 0.16 & 0.11 \\
\hline & & & & & 150 & 33.902 & 1.808 & 27.107 & 5.52 & - & 28.5 & 0.21 & 0.31 \\
\hline & & & & & 126 & 33.891 & 1.902 & 27.091 & 5.61 & 3.06 & 28.6 & 0.23 & 0.29 \\
\hline & & & & & 102 & 33.874 & 2.047 & 27.066 & 5.74 & 2.77 & 27.3 & 0.26 & 0.53 \\
\hline & & & & & 92 & 33.871 & 2.096 & 27.059 & 5.85 & 2.77 & 27.8 & 0.27 & 0.50 \\
\hline & & & & & 51 & 33.831 & 3.190 & 26.935 & 6.61 & 3.73 & 24.5 & 0.26 & 0.21 \\
\hline & & & & & 20 & 33.831 & 3.191 & 26.935 & 6.66 & 3.72 & 24.3 & 0.26 & 0.22 \\
\hline
\end{tabular}


Table A1. Continued.

\begin{tabular}{|c|c|c|c|c|c|c|c|c|c|c|c|c|c|}
\hline Station name & Long $^{\circ} \mathrm{E}$ & $\mathrm{Lat}^{\circ} \mathrm{S}$ & Seafloor, m & $\mathrm{CTD} \mathrm{N}^{\circ}$ & Depth, m & Salinity & $T_{\text {pot }}{ }^{\circ} \mathrm{C}$ & Density, $\sigma_{\theta}$ & $\delta^{15} \mathrm{~N}_{\mathrm{NO}_{3}}, \%$ & $\delta^{18} \mathrm{O}_{\mathrm{NO}_{3}}, \%$ & {$\left[\mathrm{NO}_{3}^{-}\right], \mu \mathrm{M}$} & {$\left[\mathrm{NO}_{2}^{-}\right], \mu \mathrm{M}$} & {$\left[\mathrm{NH}_{4}^{+}\right], \mu \mathrm{M}$} \\
\hline \multirow[t]{13}{*}{ E4E } & 72.56 & -48.72 & 2110 & 97 & 2194 & 34.735 & 1.256 & 27.815 & 4.82 & 2.03 & 32.6 & 0.03 & - \\
\hline & & & & & 2011 & 34.740 & 1.403 & 27.809 & 5.02 & 2.56 & 31.7 & 0.03 & - \\
\hline & & & & & 1812 & 34.744 & 1.589 & 27.798 & 4.93 & 2.18 & 31.7 & 0.03 & - \\
\hline & & & & & 1506 & 34.741 & 1.861 & 27.775 & 4.92 & 2.30 & 31.2 & 0.03 & - \\
\hline & & & & & 1255 & 34.718 & 2.066 & 27.741 & 5.08 & 2.22 & 32.5 & 0.03 & - \\
\hline & & & & & 1004 & 34.675 & 2.199 & 27.696 & 5.00 & 2.51 & 34.0 & 0.03 & - \\
\hline & & & & & 903 & 34.654 & 2.280 & 27.672 & 4.98 & 2.10 & 34.3 & 0.03 & - \\
\hline & & & & & 700 & 34.576 & 2.305 & 27.607 & 5.07 & 2.58 & 35.5 & 0.03 & - \\
\hline & & & & & 602 & 34.516 & 2.278 & 27.561 & 5.05 & 2.91 & 35.8 & 0.03 & - \\
\hline & & & & & 501 & 34.442 & 2.280 & 27.502 & 4.93 & 2.50 & 36.3 & 0.03 & - \\
\hline & & & & & 401 & 34.360 & 2.241 & 27.440 & 5.05 & 2.47 & - & - & - \\
\hline & & & & & 301 & 34.169 & 1.863 & 27.317 & 5.24 & 2.59 & 34.4 & 0.03 & - \\
\hline & & & & & 20 & 33.831 & 3.222 & 26.932 & 6.64 & 4.68 & 24.3 & 0.27 & - \\
\hline A3-2 & 72.06 & -50.62 & 527 & 107 & 509 & 34.392 & 2.184 & 27.470 & 4.87 & 2.47 & 35.4 & 0.03 & 0.01 \\
\hline & & & & & 401 & 34.288 & 2.125 & 27.392 & 4.87 & 2.39 & 35.3 & 0.03 & 0.01 \\
\hline & & & & & 300 & 34.114 & 1.906 & 27.270 & 5.16 & 2.54 & 33.1 & 0.03 & 0 \\
\hline & & & & & 276 & 34.059 & 1.804 & 27.232 & 5.33 & 2.98 & 32.8 & 0.03 & 0.02 \\
\hline & & & & & 201 & 33.941 & 1.739 & 27.143 & 5.60 & 4.16 & 31.1 & 0.27 & 0.01 \\
\hline & & & & & 175 & 33.918 & 1.942 & 27.109 & 5.76 & 4.07 & 28.1 & 0.36 & 0.30 \\
\hline & & & & & 150 & 33.912 & 2.153 & 27.088 & 6.16 & 4.07 & 26.2 & 0.34 & 0.26 \\
\hline & & & & & 126 & 33.912 & 2.162 & 27.087 & 6.42 & 4.30 & 26.2 & 0.33 & 0.21 \\
\hline & & & & & 81 & 33.912 & 2.162 & 27.087 & 6.40 & 4.66 & 26.0 & 0.33 & 0.21 \\
\hline & & & & & 39 & 33.911 & 2.242 & 27.080 & 6.41 & 5.62 & 25.7 & 0.33 & 0.17 \\
\hline & & & & & 11 & 33.911 & 2.252 & 27.079 & 6.46 & 4.48 & 25.2 & 0.33 & 0.19 \\
\hline E4W2 & 71.43 & -48.77 & 1390 & 111 & 802 & 34.568 & 2.225 & 27.608 & 4.64 & 2.44 & 34.4 & 0.02 & - \\
\hline & & & & & 601 & 34.502 & 2.227 & 27.554 & 5.45 & 3.39 & 34.9 & 0.03 & - \\
\hline & & & & & 501 & 34.440 & 2.196 & 27.508 & 4.75 & 2.64 & 34.9 & 0.03 & - \\
\hline & & & & & 401 & 34.378 & 2.166 & 27.460 & 5.09 & 3.41 & 34.3 & 0.03 & 0 \\
\hline & & & & & 300 & 34.261 & 2.020 & 27.378 & 5.40 & 3.24 & 33.8 & 0.03 & 0 \\
\hline & & & & & 251 & 34.173 & 1.897 & 27.317 & 5.07 & 2.45 & 33.1 & 0.04 & 0 \\
\hline & & & & & 201 & 34.087 & 1.792 & 27.256 & 5.01 & 3.46 & 33.4 & 0.04 & 0.01 \\
\hline & & & & & 126 & 33.902 & 1.829 & 27.105 & 5.54 & 3.84 & - & - & - \\
\hline & & & & & 126 & 33.899 & 1.893 & 27.098 & 5.39 & 3.85 & 28.0 & 0.25 & 0.60 \\
\hline & & & & & 100 & 33.884 & 2.245 & 27.058 & 6.41 & 4.79 & 26.4 & 0.27 & 0.77 \\
\hline & & & & & 75 & 33.880 & 2.551 & 27.030 & 7.91 & 5.14 & 24.4 & 0.28 & 0.56 \\
\hline & & & & & 50 & 33.872 & 2.815 & 27.001 & 7.40 & - & 23.1 & 0.28 & 0.18 \\
\hline & & & & & 11 & 33.837 & 3.076 & 26.950 & 7.02 & 5.16 & 23.3 & 0.26 & 0.06 \\
\hline E5 & 71.90 & -48.41 & 1920 & 113 & 1906 & 34.743 & 1.554 & 27.800 & 4.90 & 2.31 & 32.0 & 0.03 & - \\
\hline & & & & & 1204 & 34.716 & 2.107 & 27.736 & 5.06 & 2.05 & 32.5 & 0.03 & - \\
\hline & & & & & 1003 & 34.672 & 2.210 & 27.692 & 5.00 & 1.39 & 33.5 & 0.03 & - \\
\hline & & & & & 904 & 34.642 & 2.241 & 27.665 & 4.98 & 1.73 & 34.1 & 0.03 & - \\
\hline & & & & & 803 & 34.611 & 2.252 & 27.640 & 5.05 & 2.12 & 34.9 & 0.03 & - \\
\hline & & & & & 602 & 34.504 & 2.249 & 27.554 & 5.12 & 1.82 & 35.7 & 0.03 & - \\
\hline & & & & & 501 & 34.450 & 2.208 & 27.514 & 5.11 & 1.47 & 35.4 & 0.03 & - \\
\hline & & & & & 452 & 34.410 & 2.203 & 27.483 & 5.07 & 1.90 & 35.3 & 0.03 & - \\
\hline & & & & & 401 & 34.365 & 2.153 & 27.451 & 5.09 & 1.92 & 34.4 & 0.03 & - \\
\hline & & & & & 220 & 34.001 & 1.764 & 27.189 & 5.42 & 2.99 & 30.9 & 0.11 & - \\
\hline & & & & & 101 & 33.854 & 2.736 & 26.994 & 6.32 & 3.87 & 26.2 & 0.27 & - \\
\hline & & & & & 51 & 33.847 & 3.087 & 26.957 & 6.70 & 4.80 & 25.7 & 0.26 & - \\
\hline E5 & 71.90 & -48.41 & 1920 & 114 & 903 & 34.640 & 2.245 & 27.663 & 5.07 & 1.97 & 34.0 & 0.03 & - \\
\hline & & & & & 702 & 34.559 & 2.245 & 27.599 & 5.12 & 2.00 & 35.0 & 0.03 & - \\
\hline & & & & & 601 & 34.504 & 2.250 & 27.554 & 5.09 & 2.29 & 35.4 & 0.03 & - \\
\hline & & & & & 503 & 34.454 & 2.216 & 27.517 & 5.17 & 2.04 & 36.3 & 0.03 & - \\
\hline & & & & & 402 & 34.365 & 2.153 & 27.451 & 5.10 & 1.97 & 35.6 & 0.03 & 0 \\
\hline & & & & & 300 & 34.211 & 1.940 & 27.344 & 5.16 & 1.95 & 34.0 & 0.03 & 0 \\
\hline & & & & & 250 & 34.099 & 1.818 & 27.264 & 5.29 & 2.43 & 32.9 & 0.04 & 0 \\
\hline & & & & & 202 & 33.911 & 1.822 & 27.113 & 5.71 & 3.59 & 29.4 & 0.3 & 0.32 \\
\hline & & & & & 150 & 33.892 & 1.954 & 27.088 & 6.04 & 3.52 & 28.1 & 0.31 & 0.57 \\
\hline & & & & & 125 & 33.889 & 2.082 & 27.075 & 6.07 & 4.07 & 28.0 & 0.3 & 0.63 \\
\hline & & & & & 101 & 33.875 & 2.128 & 27.060 & 5.76 & 3.60 & 27.9 & 0.31 & 0.53 \\
\hline & & & & & 82 & 33.849 & 2.989 & 26.967 & 6.46 & 4.71 & 25.8 & 0.26 & 0.54 \\
\hline & & & & & 41 & 33.846 & 3.092 & 26.956 & 6.57 & 3.95 & 25.3 & 0.25 & 0.45 \\
\hline & & & & & 11 & 33.836 & 3.257 & 26.932 & 6.56 & 3.94 & 25.0 & 0.25 & 0.28 \\
\hline IODA & 72.89 & -48.36 & 2300 & 120 & 2278 & 34.732 & 1.171 & 27.818 & 5.03 & 2.63 & 32.7 & 0.03 & - \\
\hline RECOVERY & & & & & 2011 & 34.742 & 1.418 & 27.809 & 5.00 & 2.25 & 31.7 & 0.02 & - \\
\hline & & & & & 1809 & 34.746 & 1.615 & 27.798 & 5.02 & 1.72 & 31.7 & 0.02 & - \\
\hline & & & & & 1606 & 34.744 & 1.797 & 27.783 & 4.92 & 2.42 & 31.8 & 0.02 & - \\
\hline & & & & & 1205 & 34.714 & 2.098 & 27.735 & 5.08 & 1.86 & 33.0 & 0.02 & - \\
\hline & & & & & 1003 & 34.672 & 2.188 & 27.694 & 5.03 & 1.97 & 33.7 & 0.02 & - \\
\hline & & & & & 702 & 34.582 & 2.315 & 27.611 & 5.04 & 1.61 & 34.8 & 0.03 & - \\
\hline & & & & & 602 & 34.529 & 2.324 & 27.568 & 5.16 & 2.44 & 35.1 & 0.03 & - \\
\hline & & & & & 501 & 34.464 & 2.339 & 27.515 & 5.25 & 2.13 & 36.6 & 0.02 & - \\
\hline & & & & & 399 & 34.347 & 2.199 & 27.432 & 4.99 & 2.16 & 35.1 & 0.02 & - \\
\hline & & & & & 350 & 34.300 & 2.166 & 27.398 & 5.16 & 3.32 & 36.1 & 0.03 & - \\
\hline & & & & & 300 & 34.239 & 2.114 & 27.352 & 5.21 & 2.29 & 34.2 & 0.03 & 0.01 \\
\hline & & & & & 251 & 34.150 & 2.037 & 27.288 & 5.22 & 2.34 & 32.6 & 0.03 & 0.01 \\
\hline & & & & & 201 & 34.060 & 1.980 & 27.220 & 5.38 & 2.68 & 31.5 & 0.05 & 0.00 \\
\hline & & & & & 148 & 33.921 & 1.882 & 27.116 & 5.54 & 3.27 & 29.7 & 0.12 & 0.03 \\
\hline & & & & & 79 & 33.839 & 2.752 & 26.980 & 6.12 & 5.15 & 26.7 & 0.28 & 0.66 \\
\hline & & & & & 50 & 33.822 & 3.329 & 26.915 & 6.77 & 4.88 & 24.4 & 0.26 & 0.62 \\
\hline & & & & & 12 & 33.819 & 3.543 & 26.892 & 6.99 & 5.43 & 23.5 & 0.26 & 0.24 \\
\hline
\end{tabular}


Acknowledgements. We thank the Captain and the crew of $\mathrm{R} / \mathrm{V}$ Marion Dufresne as well as KEOPS 2 Chief scientists B. Quéguiner and S. Blain for their assistance and help during the cruise. We are grateful to the Institut Paul Emile Victor (IPEV) for having granted us access to the Marion Dufresne facilities. This work was supported by the French Research programme of INSU-CNRS LEFE-CYBER the French ANR (SIMI-6 programme, ANR10-BLAN-0614), the French CNES (Centre National d'Etudes Spatiales) and the French Polar Institute IPEV (Institut Polaire Paul-Emile Victor). The research was conducted with grants from Belgian Science Policy (BELSPO, grant SD/CA/05A); Flanders Research Foundation (FWO; grant G071512N); Vrije Universiteit Brussel, Strategic Research Plan); the Antarctic Climate and Ecosystem Cooperative Research Center (ACE-CRC, Hobart, Australia). The altimeter and colour/temperature products for the Kerguelen area were produced by Ssalto/Duacs and CLS with support from Cnes. F. Fripiat is Post-Doc at FWO, Flanders Research Foundation; C. Fernandez was partially supported by Fondap 15110027 Incar. We acknowledge the help of Natacha Brion, Leen Rymenans and Michael Korntheuer during nitrate and nitrate isotope analyses and thank the two anonymous reviewers for their constructive comments and criticisms.

Edited by: S. Blain

\section{References}

Archambeau, A.-S., Pierre, C., Poisson, A., and Schauer, B.: Distributions of oxygen and carbon stable isotopes and CFC-12 in the water masses of the Southern Ocean at $30^{\circ} \mathrm{E}$ from South Africa to Antarctica: results of the CIVA1 cruise, J. Mar. Syst., 17, 2538, 1998.

Bianchi, M., Feliatra, F., Tréguer, P., Vincendeau, M.-A., and Morvan, J.: Nitrification rates, ammonium and nitrate distribution in upper layers of the water column and in sediments of the Indian sector of the Southern Ocean, Deep-Sea Res. Pt. II, 44, 10171032, 1997.

Blain, S., Quéguiner, B., Armand, L., Belviso, S., Bombled, B., Bopp, L., Bowie, A., Brunet, C., Brussaard, C., Carlotti, F., Christaki, U., Corbière, A., Durand, I., Ebersbach, F., Fuda, J.-L., Garcia, N., Gerringa, L., Griffiths, B., Guigue, C., Guillerm, C., Jacquet, S., Jeandel, C., Laan, P., Lefèvre, D. , Lo Monaco, C., Malits, A., Mosseri, J., ObernostererI., ParkY.-H., Picheral, M., Pondaven, P., Remenyi, T., Sandroni, V., Sarthou, G., Savoye, N., Scouarnec, L., Souhaut, M., Thuiller, D., Timmermans, K., Trull, T., Uitz, J., van Beek, P., Veldhuis, M., Vincent, D., Viollier, E., Vong, L., and Wagener, T.: Effect of natural iron fertilization on carbon sequestration in the Southern Ocean, Nature, 446, 10701074, 2007.

Blain, S., Quéguiner, B., and Trull, T.: The natural iron fertilization experiment KEOPS (Kerguelen Ocean and Plateau compared Study): An overview, Deep-Sea Res. Pt. II, 55, 559-565, 2008.

Blain, S., Capparos, J., Guéneuguès, A., Obernosterer, I., and Oriol, L.: Distributions and stoichiometry of dissolved nitrogen and phosphorus in the iron fertilized region near Kerguelen (Southern Ocean), Biogeosciences, 12, 623-635, doi:10.5194/bg-12-623$2015,2015$.
Böhlke, J., Mroczkowski, S., and Coplen, T.B.: Oxygen isotopes in nitrate: New reference materials for ${ }^{18} \mathrm{O}:{ }^{17} \mathrm{O}:{ }^{16} \mathrm{O}$ measurements and observations on nitrate-water equilibrations, Rapid Comm. Mass Sp., 17, 1835-1846, 2003.

Buchwald, C., and Casciotti, K.L.: Oxygen isotopic fractionation and exchange during bacterial nitrite oxidation, Limnol. Oceanogr., 55, 1064-1074, 2010.

Casciotti, K. L.: Inverse kinetic isotope fractionation during bacterial nitrite oxidation, Geochim. Cosmochim. Acta, 73, 20612076, 2009.

Casciotti, K. L., Sigman, D. M., Hastings, M. G., Böhlke, J. K., and Hilkert, A.: Measurement of the oxygen isotopic composition of nitrate in seawater and freshwater using the denitrifier method, Anal. Chem., 74, 4905-4912, 2002.

Casciotti, K. L., Sigman, D. M., and Ward, B. B.: Linking diversity and stable isotope fractionation in ammonia-oxidizing bacteria, Geomicrobiol. J., 20, 335-353, 2003.

Casciotti, K. L., Böhlke, J. K., McIlvin, M. R., Mroczkowski, S. J., and Hannon, J. E.: Oxygen Isotopes in Nitrite: Analysis, Calibration, and Equilibration, Anal. Chem., 79, 2427-2436, 2007.

Cavagna, A. J., Lefèvre, D., Dehairs, F., Elskens, M., Fripiat,F., Closset, I., Lasbleiz, M., Flores-Leive L., Cardinal, D., Leblanc, K., Fernandez, C., Oriol, L., Blain, S., and Quéguiner, B.: Biological productivity regime in the surface water around the Kerguelen Island in the Southern Ocean - from the use of an integrative approach, Biogeosciences Discuss., 11, 18073-18104, doi:10.5194/bgd-11-18073-2014, 2014.

Church, M. J., DeLong, E. F., Ducklow, H. W., Karner, M. B., Preston, C. M., and Karl, D. M.: Abundance and distribution of planktonic Archaea and Bacteria in the waters west of the Antarctic Peninsula, Limnol. Oceanogr., 48, 1893-1902, 2003.

Closset, I., Lasbleiz, M., Leblanc, K., Quéguiner, B., Cavagna, A.J., Elskens, M., Navez, J., and Cardinal, D.: Seasonal evolution of net and regenerated silica production around a natural $\mathrm{Fe}$ fertilized area in the Southern Ocean estimated from Si isotopic approaches, Biogeosciences, 11, 5827-5846, doi:10.5194/bg-115827-2014, 2014.

DiFiore, P. J., Sigman, D. M., Trull, T. W., Lourey, M. J., Karsh, K., Cane, G., and Ho, R.: Nitrogen isotope constraints on subantarctic biogeochemistry, J. Geophys. Res., 111, C08016, doi:10.1029/2005JC003216, 2006.

DiFiore, P. J., Sigman, D. M., and Dunbar, R. B.: Upper ocean nitrogen fluxes in the Polar Antarctic Zone: constraints from the nitrogen and oxygen isotopes of nitrate, Geochem., Geophys. Geosyst., 10, Q11016, doi:10.1029/2009GC002468, 2009.

DiFiore, P. J., Sigman, D. M., Karsh, K. L., Trull, T. W., Dunbar, R. B., and Robinson, R. S.: Poleward decrease in the isotope effect of nitrate assimilation across the Southern Ocean, Geophys. Res. Lett., 37, L17601, doi:10.1029/2010GL044090, 2010.

Fogel, M. L. and Cifuentes, L. A.: Isotope fractionation during primary production, in: Organic Geochemistry, edited by: Engel, M. H. and Macko, S. A, Plenum Press, NY, 73-98, 1993.

Fripiat, F., Sigman, D. M., Fawcett, S. E., Rafter, P. A., Weigand, M. A., and Tison, J.-L.: New insights into sea ice nitrogen biogeochemical dynamics from the nitrogen isotopes, Global Biogeochem. Cy., 28, 115-130, doi:10.1002/2013GB004729, 2014.

Fripiat, F., Elskens, M., Trull, T. W., Blain, S., Cavagna, A. J., Fernandez, C., Fonseca-Batista, D., Planchon, F., Raimbault, P., Roukaerts, A., and Dehairs, F.: Significant mixed layer nitrifi- 
cation in a natural iron-fertlized bloom of the Southern Ocean, Global Biogeochem. Cy., in review, 2015.

Fukamachi, Y., Rintoul, S. R., Church, J. A., Aoki, S., Sokolov, S., Rosenberg, M. A., and Wakatsuchi, M.: Strong export of Antarctic bottom water east of the Kerguelen Plateau, Nat. Geosci., 3, 327-331, 2010

Gille, S. T., Carranza, M. M., Cambra, R., and Morrow, R.: Windinduced upwelling in the Kerguelen Plateau Region, Biogeosciences, 11, 6389-6400, doi:10.5194/bg-11-6389-2014, 2014.

González, M. L., Molina, V., Florez-Leiva, L., Oriol, L., Cavagna, A. J., Dehairs, F., Farias, L., and Fernandez, C.: Nitrogen fixation in the Southern Ocean: a case of study of the Fe-fertilized Kerguelen region (KEOPS II cruise), Biogeosciences Discuss., 11, 17151-17185, doi:10.5194/bgd-11-17151-2014, 2014.

Granger, J., Sigman, D. M., Needoba, J. A., and Harrison, P. J.: Coupled nitrogen and oxygen isotope fractionation of nitrate during assimilation by cultures of marine phytoplankton, Limnol. Oceanogr., 49, 1763-1773, 2004.

Granger, J., Sigman, D. M., Lehmann, M. F., and Tortell, P. D.: Nitrogen and oxygen isotope fractionation during dissimilatory nitrate reduction by denitrifying bacteria, Limnol. Oceanogr., 53, 2533-2545, 2008.

Granger, J., Sigman, D. M., Rohde, M. M., Maldonado, M. T., and Tortell, P. D.: $\mathrm{N}$ and $\mathrm{O}$ isotope e?ects during nitrate assimilation by unicellular prokaryotic and eukaryotic plankton cultures, Geochim. Cosmochim. Ac., 74, 1030-1040, 2010.

Granger, J., Prokopenko, M. G., Sigman, D. M., Mordy, C. W., Morse, Z. M., Morales, L. V., Sambrotto, R. N., and Plessen, B.: Coupled nitrification-denitrification in sediment of the eastern Bering Sea shelf to ${ }^{15} \mathrm{~N}$ enrichment of fixed $\mathrm{N}$ in shelf waters, $\mathrm{J}$. Geophys. Res., 116, C11006, doi:10.1029/2010JC006751, 2011.

Granger, J., Prokopenko, M. G., Mordy, C. W., and Sigman, D. M.: The proportion of remineralized nitrate on the ice-covered eastern Bering Sea shelf evidenced from the oxygen isotope ratio of nitrate, Global Biogeochem. Cy., 27, 962-971, 2013.

Guerrero, M. A. and Jones, R. D.: Photoinhibition of marine nitrifying bacteria 1. Wavelength-dependent response, Mar. Ecol. Prog. Ser. 141, 183-192, 1996.

Hoch, M. P., Fogel, M. L., and Kirchman, D. L.: Isotope fractionation associated with ammonium uptake by a marine bacterium, Limnol. Oceanogr., 37, 1447-1459, 1992.

Jacquet, S. H. M., Dehairs, F., Savoye, N., Obernosterer, I., Christaki, U., Monnin, C., and Cardinal, D.: Mesopelagic organic carbon remineralization in the Kerguelen Plateau region tracked by biogenic particulate Ba, Deep-Sea Res. Pt. II, 55, 868-879, 2008.

Jacquet, S. H. M., Dehairs, F., Cavagna, A. J., Planchon, F., Monin, L., André, L., Closset, I., and Cardinal, D.: Early season mesopelagic carbon remineralization and transfer e?ciency in the naturally iron-fertilized Kerguelen area, Biogeosciences Discuss., 11, 9035-9069, doi:10.5194/bgd-11-9035-2014, 2014.

Kendall, C.: Tracing nitrogen sources and cycling in catchments, in: Isotope Tracers in Catchment Hydrology, edited by: Kendall, C., and McDonnell, J. J., Elsevier, 519-576, 1998.

Knapp, A. N., Sigman, D. M., Lipschultz, F., Kustka, A. B., and Capone, D. G.: Interbasin isotopic correspondence between upper ocean bulk DON and subsurface nitrate and its implications for marine nitrogen cycling, Global Biogeochem. Cy., 25, GB4004, doi:10.1029/2010GB003878, 2011.
Lasbleiz, M., Leblanc, K., Blain, S., Ras, J., Cornet-Barthaux, V., Hélias Nunige, S., and Quéguiner, B.: Pigments, elemental composition $(\mathrm{C}, \mathrm{N}, \mathrm{P}, \mathrm{Si})$ and stoichiometry of particulate matter, in the naturally iron fertilized region of Kerguelen in the Southern Ocean, Biogeosciences, 11, 5931-5955, doi:10.5194/bg-115931-2014, 2014.

Martens-Habbena, W., Berube, P. M., Urakawa, H., de la Torre, J. R., and Sath, D. A.: Ammonia oxidation kinetics determine niche separation of nitrifying Archaea and Bacteria, Nature, 461, 976979, 2009.

McCartney, M. S. and Donohue, K. A.: A deep cyclonic gyre in the Australian-Antarctic Basin, Prog. Oceanogr., 75, 675-750, 2007.

Möbius, J.: Isotope fractionation during nitrogen remineralization (ammoni?cation): Implications for nitrogen isotope biogeochemistry, Geochim. Cosmochim. Ac., 105, 422-432, 2013.

Mosseri, J., Quéguiner, B., Armand, L., and Cornet-Barthaux, V.: Impact of iron on silicon utilization by diatoms in the Southern Ocean: a case of $\mathrm{Si} / \mathrm{N}$ cycle decoupling in a naturally ironenriched area, Deep-Sea Res. Pt. II, 55, 801-819, 2008.

Mulholland, M. R. and Lomas, M. W.: Nitrogen uptake and assimilation, in: Nitrogen in the Marine Environment, edited by: Mulholland, M. R. and Capone, D. J., Elsevier, 303-384, 2008.

Olson, R. J.: $15-\mathrm{N}$ tracer studies of the primary nitrite maximum, J. Mar. Res., 39, 203-226, 1981a.

Olson, R. J.: Differential photoinhibition of marine nitrifying bacteria - a possible mechanism for the formation of the primary nitrite maximum, J. Mar. Res., 39, 227-238, 1981 b.

Park, Y.-H., F. Roquet, I. Durand, and Fuda, J.-L.: Large-scale circulation over and around the Northern Kerguelen Plateau, DeepSea Res. Pt. II, 55, 566-581, 2008.

Park, Y.-H., Durand, I., Kestenare, E., Rougier, G., Zhou, M., d'Ovidio, F., Cottéa, C., and Lee, J.-H.: Polar Front around the Kerguelen Islands: an up-to-date determination and associated circulation of surface/subsurface waters, J. Geophys. Res.Oceans, 119, 6575-6592, doi:10.1002/2014JC010061, 2014.

Paul, D., Skrzypek, G., and Fórizs, I.: Normalization of measured stable isotopic compositions to isotope reference scales - a review, Rapid Commun. Mass Sp., 21, 3006-3014, 2007.

Pennock, J. R., Velinsky, D. J., Ludlam, J. M., and Sharp, J. H.: Isotopic fractionation of ammonium and nitrate during uptake by Skeletonema costatum: implications for $\delta^{15} \mathrm{~N}$ dynamics under bloom conditions, Limnol. Oceanogr., 41, 451-459, 1996.

Planchon, F., Ballas, D., Cavagna, A.-J., Van Der Merwe, P., Bowie, A., Trull, T., Laurenceau, E., Davis, D., and Dehairs, F.: Carbon export in the naturally iron-fertilized Kerguelen area of the Southern Ocean using ${ }^{234} \mathrm{Th}$-based approach, Biogeosciences Discuss., doi:10.5194/bgd-11-15991-2014, 2014.

Rafter, P. A., DiFiore, P. J., and Sigman, D. M.: Coupled nitrate nitrogen and oxygen isotopes and organic matter remineralization in the Southern and Paci?c Oceans, J. Geophys. Res.-Oceans, 118, 4781-4794, 2013.

Sigman, D. M., Altabet, M. A., McCorkle, D. C., Francois, R., and Fischer, G.: The $\delta^{15} \mathrm{~N}$ of nitrate in the Southern Ocean: Consumption of nitrate in surface waters, Global Biogeochem. Cy., 13, 1149-1166, 1999.

Sigman, D. M., Altabet, M. A., McCorkle, D. C., Francois, R., and Fischer, G.: The $\delta^{15} \mathrm{~N}$ of nitrate in the Southern Ocean: Nitrogen 
cycling and circulation in the ocean interior, J. Geophys. Res.Oceans, 105, 19599-19614, 2000.

Sigman, D. M., Casciotti, K. L., Andreani, M., Barford, C., Galanter, M., and Böhlke, J. K.: A bacterial method for nitrogen isotopic analysis of nitrate in seawater and freshwater, Anal. Chem., 73, 4145-4153, 2001.

Sigman, D., Granger, J., DiFiore, P., Lehmann, M. M., Ho, R., Cane, G., and van Geen, A.: Coupled nitrogen and oxygen isotope measurements of nitrate along the eastern North Pacific margin, Global Biogeochem. Cy., 19, GB4022, doi:10.1029/2005GB002458, 2005.

Sigman, D. M., Karsh, K. L., and Casciotti, K. L.: Nitrogen isotopes in the ocean, in: Encyclopedia of Ocean Sciences, edited by: Steele, J. H., Turekian, K. K., and Thorpe, S. A., Elsevier, 25, 40-54, 2009a.

Sigman, D. M., DiFiore, P. J., Hain, M. P., Deutsch, C., Wang, Y., Karl, D. M., Knapp, A. N., Lehmann, M. F., and Pantoja, S.: The dual isotopes of deep nitrate as a constraint on the cycle and budget of oceanic fixed nitrogen, Deep-Sea Res. Pt. I, 56, 14191439, 2009b.

Stahl, D. A. and de la Torre, J.: Physiology and diversity of ammonia-oxidizing archaea, Annu. Rev. Microbiol., 66, 88-101, 2012.

Trull, T. W., Davies, D., and Casciotti, K.: Insights into nutrient assimilation and export in naturally iron-fertilized waters of the Southern Ocean from nitrogen, carbon and oxygen isotopes, Deep-Sea Res. Pt. II, 55, 820-84, 2008.
Trull, T. W., Davies, D. M., Dehairs, F., Cavagna, A.-J., Lasbleiz, M., Laurenceau, E. C., d'Ovidio, F., Planchon, F., Leblanc, K., Quéguiner, B., and Blain, S.: Chemometric perspectives on plankton community responses to natural iron fertilization over and downstream of the Kerguelen Plateau in the Southern Ocean, Biogeosciences, 12, 1029-1056, doi:10.5194/bg-12-1029-2015, 2015.

Wankel, S. D., Kendall, C., Pennington, J. T., Chavez, F. P., and Paytan, A.: Nitrification in the euphotic zone as evidence by nitrate dual isotopic composition; Observations from Monterey Bay, California, Global Biogeochem. Cy., 21, GB2009, doi:10.1029/2006GB002723, 2007.

Waser, N. A. D., Harrison, P. J., Nielsen, B., Calvert, S. E., and Turpin, D. H.: Nitrogen isotope fractionation during the uptake and assimilation of nitrate, nitrite, ammonium and urea by a marine diatom, Limnol. Oceanogr., 43, 215-224, 1998.

Waser, N. A., Yu, Z., Yin, K., Nielsen, B., Harrison, P. J., Turpin, D. H., and Calvert, S. E.: Nitrogen isotopic fractionation during a simulated diatom spring bloom: importance of $\mathrm{N}$ starvation in controlling fractionation, Mar. Ecol.-Prog. Ser., 179, 291-296, 1999.

Yool, A., Martin, A. P., Fernández, C., and Clark, D. R.: The significance of nitrification for oceanic new production, Nature, 447, 999-1002, 2007. 